\title{
Ekonomia prestiżu akademickiego. llościowe ujęcie najlepszych czasopism na przykładzie dziedziny badań nad szkolnictwem wyższym
}

\begin{abstract}
STRESZCZENIE: Niniejsze studium dotyczy stratyfikacji (rozwarstwienia) w globalnym środowisku badaczy szkolnictwa wyższego oraz zmieniającej się geografii afiliacji autorów prac w sześciu najbardziej elitarnych czasopismach naukowych w tym obszarze. Model maksymalizacji prestiżu przez instytucje i naukowców oraz teoria pryncypała-agenta stanowią dwie ramy teoretyczne badania, które obejmuje 6334 artykuły opublikowane w sześciu prestiżowych czasopismach w latach 1996-2018 w kontekście 21442 artykułów opublikowanych w 41 podstawowych czasopismach w badanym obszarze. Porównano autorów zajmujących się szkolnictwem wyższym w pełnym i niepełnym wymiarze („etatowcy” i „niepełnoetatowcy”, full-timers i part-timers) i przeanalizowano rozkład ich przynależności do poszczególnych krajów z longitudinalnej (podłużnej) perspektywy ostatniego ćwierćwiecza. Wyniki wskazują, że około 3,3\% naukowców publikujących zarówno w czasopismach elitarnych, jak i podstawowych, będących autorami co najmniej 5 artykułów w latach 1996-2018 stanowi trzon wydawniczy globalnej społeczności badawczej, podczas gdy 80\% badaczy, którzy są autorami tylko jednego artykułu, stanowi jej peryferie. Pisma Higher Education i Studies in Higher Education wyłaniają się jako globalne czasopisma elitarne, z rosnącym udziałem prac autorów nieanglosaskich. Globalne trendy w obszarze badań nad szkolnictwem wyższym obejmują malejącą rolę naukowców amerykańskich oraz rosnącą rolę naukowców z Europy kontynentalnej i Azji Wschodniej.
\end{abstract}

SŁOWA KLUCZOWE: prestiż w nauce, ilościowe badania nauki, stratyfikacji czasopism naukowych, prestiżowe publikacje, ekonomia prestiżu, model pryncypała-agenta, model maksymalizacji prestiżu, nauka globalna

\section{Wprowadzenie}

Poszukiwanie prestiżu poprzez publikowanie w najlepszych czasopismach naukowych ma kluczowe znaczenie w tzw. ,ekonomii prestiżu” w szkolnictwie wyższym (Blackmore i Kandiko 2011; Rosinger i in. 2016; Kandiko Howson i in. 2018). Na wszystkich poziomach - od systemu krajowego, przez instytucje, wydziały, aż po indywidualnych 
naukowców - globalna wspólnota akademicka konkuruje na rynkach prestiżu, na których „ "prestiż» oznacza szczególny rodzaj rynku - taki, na którym to, co jest uznane i czym się posługujemy, nie musi mieć bezpośredniej wartości finansowej” (Blackmore 2016: 10). Prestiż może być akumulowany i wiąże się z badaniami naukowymi, a nie z misją dydaktyczną czy usługową (czy jakąkolwiek „trzecią misją”) uczelni (Marginson 2014; Melguizo i Strober 2007; Leslie i Slaughter 1997). Poprzez prowadzone badania instytucje i naukowcy są mocno zaangażowani w działania mające na celu maksymalizację prestiżu (Taylor i in. 2016; Rosinger i in. 2016), takie jak publikowanie w najważniejszych czasopismach czy też starania o najbardziej niedostępne granty. Prestiż łączy się nieodmiennie z selektywnością - i stratyfikuje kadrę akademicką, grupy badawcze, uczelnie i ich części składowe.

Ekonomia prestiżu elitarnych czasopism poświęconych badaniom naukowym w szkolnictwie wyższym (zwanym higher education research) jest funkcją niedoboru (określeń „elitarne”, „prestiżowe” i „najlepsze” używamy tutaj wymiennie); górne 10\% czasopism zawsze będzie miało ograniczoną liczbę, choć z czasem wielkość oferowanego przez nie miejsca może rosnąć. Miejsce jest zasobem deficytowym tylko dla najlepszych czasopism, z bardzo wysokim wskaźnikiem odrzuconych tekstów wynoszącym 90\% i więcej. Rzeczywiście, „prestiż wymaga niedoboru” (Blackmore 2018: 234), a liczba naukowców chcących publikować w najlepszych czasopismach przewyższa dostępne w danym momencie miejsce, podobnie jak w przypadku prestiżowych grantów i stypendiów. Kierunek zachodzących zmian jest czytelny: chętnych przybywa, możliwości ubywa, i to w większości obszarów nauki. Wartość rzadkiego dobra społecznego rośnie przez sam fakt, że inni nie mogą go łatwo posiąść (Blackmore 2018: 245), a lista prestiżowych czasopism w każdej dziedzinie jest zawsze krótka, dając satysfakcję publikacji tylko nielicznym. Każda dziedzina ma swoje własne czasopisma z górnej półki, a idea „tyranii pierwszej piątki” (Heckman i Moktan 2018) ma zastosowanie daleko poza ekonomią. Jednak nie wszystkie instytucje i nie wszyscy naukowcy są w takim samym stopniu zaangażowani w grę o prestiż; niektóre instytucje nie poszukują prestiżu, a niektórzy naukowcy nie publikują, co szczegółowo zdiagnozowaliśmy dla 11 krajów Europy (to non-performers czy non-publishers, obecni w każdym systemie, choć w Polsce wyjątkowo liczni, zob. Kwiek 2019a; Kwiek 2015a).

Jak pokazuje obszerna międzynarodowa literatura ostatniej dekady, sukces akademicki w wielu różnych dyscyplinach w dzisiejszym konkurencyjnym, poszukującym zasobów środowisku akademickim zależy w dużej mierze od publikowania w najbardziej prestiżowych czasopismach. W związku z tym, podczas gdy najlepsze czasopisma poświęcone badaniom z zakresu szkolnictwa wyższego coraz częściej zmagają się z zalewem zgłoszeń, czasopisma znajdujące się bliżej końca prestiżowego „porządku dziobania" walczą o pozyskiwanie autorów. Powód jest prosty: miejsce wydania tekstu ma ogromne - i najczęściej rosnące - znaczenie dla osób, instytucji i krajów podlegających 
ciągłym procedurom rankingowym, ewaluacyjnym, oceniającym i selekcjonującym. W ekonomii prestiżu kariery akademickie stały się „przeliczalne ilościowo w sposób niewyobrażalny jeszcze kilkadziesiąt lat temu" (Kandiko Howson i in. 2018: 1).

Niniejsze studium analizuje zmiany w globalnym środowisku badaczy szkolnictwa wyższego poprzez badanie trendów publikacyjnych w sześciu najbardziej prestiżowych czasopismach naukowych tego obszaru. W szczególności z nowej, podłużnej (longitudinalnej) perspektywy (1996-2018) analizowane jest niepokojące rozróżnienie między autorami pełnoetatowymi i niepełnoetatowymi w tym obszarze (po raz pierwszy wspomniane przez Santosa i Hortę 2018), czyli „etatowcami” i „niepełnoetatowcami” (full-timers i part-timers) oraz rozkład krajowych afiliacji autorów publikacji. Globalne zmiany w społeczności akademickiej zajmującej się badaniami szkolnictwa wyższego znajdują odzwierciedlenie w zmieniającym się w czasie rozkładzie krajowych afiliacji. Malejący wpływ badaczy amerykańskich jest związany z równoczesnym wzrostem aktywności badawczej naukowców z innych regionów, zwłaszcza z Europy kontynentalnej i Azji Wschodniej.

Niniejsza praca koncentruje się na najwyższych warstwach globalnych czasopism w badanym obszarze (a zaproponowane tu procedury można wykorzystać dla dowolnego obszaru nauki i jego najlepszych czasopism; studium jest w tym sensie w pełni replikowalne - $\mathrm{i}$ transferowalne do innych obszarów). W sumie przeanalizowano 6334 artykuły opublikowane w sześciu elitarnych czasopismach z lat 1996-2018 w kontekście 21442 artykułów z 41 czasopism uznanych za podstawowe. Elitarne czasopisma bywają różnie określane: „centralne” (Bayer 1983), „kluczowe” (Hutchinson i Lovell 2004) czy „,wiodące” (Tight 2014); wydzielano pierwszą, drugą i trzecią warstwę czasopism w nieformalnym „porządku dziobania” (Bayer 1983: 103) czy w ramach funkcjonującego „systemu kastowego” czasopism (Bray i Major 2011).

Często cytowane publikacje wydawane w prestiżowych czasopismach są szczególnie ważne w krajowych systemach o konkurencyjnych strukturach kariery naukowej i rygorystycznych systemach ewaluacji badań (Whitley i Gläser 2007) - lub w systemach zmierzających w tym kierunku, do których należy system polski. Ewaluacja jest często oparta na klasyfikacjach czasopism z bazy Web of Science lub Scopus jako wyznacznikach jakości naukowej, a w wielu krajach nowe systemy nagradzania oceniają indywidualne i instytucjonalne wyniki badań pod kątem prestiżu czasopism oraz liczby opublikowanych w nich prac. Zachęty finansowe dodatkowo wpływają na decyzje o tym, gdzie i jak często należy nadsyłać artykuły do publikacji (Bak i Kim 2019: 219ff.). Istnieją liczne dowody na to, że publikacje w najbardziej prestiżowych czasopismach są najlepszym predyktorem wynagrodzenia kadry akademickiej na uniwersytetach prowadzących intensywną działalność badawczą (Gomez-Mejia i Balkin 1992: 942; Heckman i Moktan 2018; Kwiek 2018a). Istnieją również dowody na efekt sprzężenia zwrotnego, ponieważ czasopismo, w którym publikowana jest praca, 
ma silny wpływ na wskaźniki cytowania danej publikacji (i jest to tzw. efekt Nature); innymi słowy, usytuowanie pracy w pionowo rozwarstwionym systemie publikacyjnym zazwyczaj decyduje o jej wpływie. Dlatego też związany z czasopismami efekt Mateusza zapewnia artykułom „wartość dodaną wykraczającą poza ich wewnętrzną jakość" (Larivière i Gingras 2010: 424). Ma znaczenie wartość publikacji - i ma znaczenie jej ulokowanie w zestratyfikowanym systemie czasopism.

Awans, uznanie i wynagrodzenia akademickie są ściśle związane z publikowaniem w najlepszych czasopismach w wielu dyscyplinach, a pojawienie się nowych czasopism akademickich daje badaczom szkolnictwa wyższego więcej możliwości zwiększania swojej widoczności. Podobne procesy dotyczą większości dziedzin: rośnie liczba czasopism i poszerza się dostępne miejsce. Jednak pozornie racjonalna decyzja, aby „oszczędzać czas i [...] szybciej dotrzeć do tej samej populacji i potencjalnie uzyskać jak największą liczbę cytowań” (Larivière i in. 2014: 654) jest tylko częścią logiki sukcesu naukowego w ramach ekonomii prestiżu, ponieważ tylko publikacje w elitarnych czasopismach pozostają kluczowym wyznacznikiem naukowego uznania. Na przykład w dziedzinie ekonomii „publikowanie w T5 (top five, pięciu najlepszych czasopismach) jest najskuteczniejszym sposobem zwiększania szans na zdobycie pracy we wszystkich 35 najlepszych amerykańskich wydziałach ekonomii” (Heckman i Moktan 2018: 6).

Niniejsze studium zajmuje się dwoma pytaniami badawczymi z perspektywy przekrojowej i longitudinalnej (podłużnej). (1) W jaki sposób globalna społeczność badaczy szkolnictwa wyższego jest rozwarstwiona pod względem intensywności zaangażowania w publikowanie w elitarnych czasopismach? (2) Jakie zmiany można zaobserwować w geografii krajowych afiliacji autorskich w czasopismach elitarnych? Zmiany są konceptualizowane na poziomie poszczególnych naukowców w ramach pytania (1) oraz na poziomie krajowych afiliacji w ramach pytania (2). Po nakreśleniu podstaw teoretycznych w artykule opisano źródła danych i metodologię. Następnie przedstawione zostały wyniki empiryczne, po czym przedstawiono dyskusję i wnioski.

\section{Podstawy teoretyczne - elitarne czasopisma naukowe w systemie produkcji wiedzy akademickiej}

Dwa istotne nurty badawcze pomagają wyjaśnić potężny wpływ publikowania wyników badań naukowych w elitarnych czasopismach na środowisko akademickie, instytucje i krajowe systemy nauki (oraz na naukę globalną):

(1) Model maksymalizacji prestiżu instytucji szkolnictwa wyższego. W ramach szerszych teorii kapitalizmu akademickiego i teorii uzależnienia od zasobów, model ten łączy rolę publikacji w prestiżowych czasopismach z systemami wynagrodzeń i nagród w nauce. 
(2) Teoria agencji (pryncypała-agenta) wyjaśnia, jak publikowanie w prestiżowych czasopismach godzi interesy poszczególnych naukowców (jako agentów) z interesami ich instytucji i organizacji sponsorujących badania, w tym rządów krajowych (jako zleceniodawców czy pryncypałów).

\subsection{Model maksymalizacji prestiżu instytucji szkolnictwa wyższego a czasopisma elitarne}

Zgodnie z tym modelem uczelnie prowadzące intensywną działalność badawczą, jak również ich wydziały i poszczególni naukowcy, działają w dużej mierze jako „maksymalizatorzy prestiżu” (Melguizo i Strober 2007: 634), nieustannie dążąc do maksymalizacji swojego prestiżu. Tak jak firmy są „maksymalizatorami zysku”, tak uczelnie poszukują głównie prestiżu na styku ekonomii monetarnej i ekonomii prestiżu. Podczas gdy ekonomia monetarna zapewnia niezbędne środki finansowe, wspólnoty dyscyplinarne i zawodowe „przyznają kapitał społeczny i kulturowy w ramach ekonomii prestiżu" (Blackmore i Kandiko 2011: 405). Prestiż może być również wykorzystywany jako dźwignia do pozyskiwania zasobów, głównie poprzez granty badawcze, a instytucje, wydziały i poszczególni naukowcy modyfikują swoje zachowania - w tym także swoje wzorce publikacyjne - rywalizując o zasoby na wewnętrznych i zewnętrznych quasi-rynkach naukowych (Taylor i in. 2013).

Na tych konkurencyjnych quasi-rynkach naukowych publikacje w elitarnych czasopismach odgrywają coraz większą rolę, zwłaszcza w następstwie rozwoju i kodyfikacji systemów ewaluacji badań w Europie (Whitley i Gläser 2007). Nie wszystkie czasopisma mają bowiem jednakową renomę, a „nadrzędną pozycję zajmują ci, którzy angażują się w działania przyczyniające się do wysokiego statusu uniwersytetów" (Slaughter i Leslie 1997: 116). Podczas gdy instytucje i poszczególne jednostki korzystają z szerokiego wachlarza zasobów zewnętrznych (i, analogicznie, długiej listy czasopism), nie wszystkie zasoby i nie wszystkie czasopisma w równym stopniu przyczyniają się do akumulacji prestiżu (Rosinger i in. 2016: 28-29; Taylor i in. 2016: 106-107). Istnieje wyraźna tendencja do preferowania czasopism elitarnych i wysoce konkurencyjnych grantów badawczych.

Model ten podkreśla indywidualne generowanie prestiżu poprzez publikacje, granty badawcze, patenty i nagrody jako kluczowe zasoby dla uniwersytetów prowadzących intensywną działalność badawczą. W tej „konkurencyjnej ekonomii opierającej się na statusie" (Marginson 2014: 107) badania naukowe są potężnym źródłem zróżnicowania i uporządkowania rangi naukowców i instytucji, a prestiż jest główną siłą napędową tego, co Slaughter i Leslie (1997) nazwali „kapitalizmem akademickim”, który ma obecnie zasięg globalny (zob. Cantwell i Kauppinen 2014). W całej Europie, w „organizacjach pracy opartych na renomie”, takich jak uniwersytety (Whitley 2000: 25), cykl wiarygodności, który umożliwia europejskim naukowcom 
rozwijanie się w swojej dziedzinie (Latour i Woolgar 1986: 201-208), polega na przekształcaniu prestiżowych artykułów w naukowe uznanie, co prowadzi do pozyskiwania indywidualnego, konkurencyjnego finansowania opartego na grantach, które jest następnie przekształcane w nowe dane, argumenty i artykuły (zob. Cruz-Castro i Sanz-Menéndes 2010, którzy badali związek między osiągnięciami naukowymi a nagrodami w formie otrzymania stałej pracy przez początkujących naukowców). Publikacje w prestiżowych czasopismach zwiększają szanse europejskich naukowców na zapewnienie sobie stanowisk akademickich, szybszy awans zawodowy i przyciągnięcie zewnętrznego finansowania w ramach osiągania statusu globalnej elity naukowej (Kwiek 2016). Ekonomia prestiżu selekcjonuje i waloryzuje zewnętrzne zasoby badawcze i sprzyja publikacjom w najważniejszych czasopismach, co prowadzi do segmentacji w obrębie uniwersytetów, rozdzielenia wydziałów o wysokich i niskich zasobach oraz odpowiedniego dla nich ksztaltowania karier naukowych (Rosinger i in. 2016). Segmentacja zachodzi we wszystkich instytucjach o zróżnicowanym dostępie do wysoce selektywnych środków zewnętrznych - ale najważniejsza linia wewnątrzinstytucjonalnych podziałów biegnie między dziedzinami (i wydziałami) humanistycznymi (i częściowo w ramach nauk społecznych) i dziedzinami (i wydziałami) związanymi ze STEM (science, technology, engineering, mathematics; w polskim kontekście wystarczy porównać środki otrzymane z NCN w ramach największych instytucji w ostatniej dekadzie w ramach badań edukacyjnych i badań chemicznych).

Model ten postrzega prestiż przede wszystkim jako dobro rywalizacyjne, oparte na miarach względnych, a nie bezwzględnych - jako grę o sumie zerowej, w której „to, co wygrywają zwycięzcy, przegrywają przegrani” (Hirsch 1976: 52) - jako że akademia staje się coraz bardziej konkurencyjna, sterowana przez politykę państwa świadomie podkreślającą „prestiż na wszystkich poziomach od systemu narodowego do jednostki” (Blackmore 2016: 1). Podobnie jak poszczególni naukowcy, również uczelnie konkurują na rynkach prestiżu opartych na tradycyjnym etosie pracy naukowej, gdzie publikacje są wysoko cenione. W szczególności model ten tworzy silny związek pomiędzy prestiżem indywidualnym i instytucjonalnym: „maksymalizując swój indywidualny prestiż, naukowcy jednocześnie maksymalizują prestiż swoich wydziałów i instytucji” (Melguizo i Strober 2007: 635). Wynika z tego, że osoby, które przyczyniają się do podnoszenia prestiżu swoich instytucji, są premiowane wyższymi wynagrodzeniami (Bak i Kim 2019), ponieważ większa liczba publikacji w prestiżowych czasopismach i bardziej prestiżowe granty badawcze podnoszą prestiż instytucjonalny. (Teoria stałego prestiżu wydziałów zaproponowana przez Burrisa (2004) odnosi się przede wszystkim do dużego systemu amerykańskiego - z długą listą prestiżowych wydziałów socjologii w całym kraju i ewentualną mobilnością kadry między nimi, i ma niewielkie zastosowanie w Europie kontynentalnej). Model ten wyraźnie zakłada celowe zachowanie wszystkich aktorów w dążeniu do realizacji własnych interesów 
i do zdobywania prestiżu. W szczególności zakłada on istnienie konkurencyjnych rynków w szkolnictwie wyższym i w nauce (Melguizo i Strober 2007: 635).

Teoria kapitalizmu akademickiego zakłada, że uniwersytety anglosaskie reorientują się, by wygrać tę grę o prestiż i zasoby (Taylor i in. 2016); badania naukowe mają zwykle pierwszeństwo przed kształceniem, a wzrost finansowania badań ze środków publicznych dodatkowo wzmacnia ekonomię prestiżu (Rosinger i in. 2016; Kandiko Howson i in. 2018). Na całym świecie polityka krajowa, instytucjonalna i wydziałowa oraz procedury oceny działalności badawczej nadają priorytet prestiżowym czasopismom (najlepszym ostatnim przykładem w Polsce są nowe zasady ewaluacji kadry akademickiej i reguły oceny dorobku oraz oceny planów rozwojowych uczelni, które wygrały konkurs na polskie „uczelnie badawcze” na lata 2020-2026). Uczelnie (i poszczególni naukowcy) muszą konkurować o krytyczne zasoby, a zgodnie z teorią kapitalizmu akademickiego publikacje w elitarnych czasopismach stanowią kluczowy wymiar konkurencji (Slaughter i Leslie 1997: 114) jako najważniejszego mechanizmu rozwoju nauki (Kwiek 2018c).

\subsection{Teoria pryncypała-agenta a czasopisma elitarne}

W omawianym kontekście teoria agencji (pryncypała-agenta) rzuca światło na wykorzystywanie metryk opartych na prestiżu do stratyfikacji czasopism akademickich w krajowych i instytucjonalnych systemach oceny badań (Whitley i Gläser 2007). Metryki te są coraz częściej wykorzystywane przez rządy i ich agencje, krajowe organy finansujące badania oraz instytucje akademickie (Kwiek 2019a; Kwiek 2019c). Podczas gdy teoria ta była wcześniej stosowana głównie w badaniach dotyczących przedsiębiorstw (Pratt i Zeckhauser 1985), była również stosowana w szkolnictwie wyższym (Kivistö 2008; Urbanek 2018) i sektorze nauki (Braun i Guston 2003; van der Meulen 1998). W relacjach między uczelnią jako agentem a państwem i jego agencjami jako pryncypałem (zleceniodawcą) publikacje w prestiżowych czasopismach są kluczowym wskaźnikiem produktywności i krytycznym elementem w rywalizacji o finansowanie badań.

Literatura dotycząca teorii agencji zajmuje się w szczególności społeczną relacją delegacji. Wiąże się to z wymianą zasobów pomiędzy podmiotami, w której agent przyjmuje zasoby pryncypała i zobowiązuje się do dbałości o jego interesy (Braun i Guston 2003). W omawianym przypadku agentami są uczelnie i poszczególni naukowcy, a pryncypałami są rządy i krajowe instytucje finansujące badania, reprezentujące interesy zarówno państwa, jak i środowiska akademickiego. Gdy zleceniodawca deleguje władzę, angażując agenta do wykonywania pewnych zadań w jego imieniu, często ma trudności z kontrolowaniem agenta, którego cele mogą się różnić od jego własnych, szerszych, publicznych celów. Na przykład naukowcy mogą decydować się na publikowanie w czasopismach, które oferują łatwy dostęp, mogą nadmiernie angażować się w konsulting lub markować uprawianie badań naukowych (na różne dobrze im znane sposoby). 
Takim relacjom asymetrii informacyjnej między zleceniodawcami i agentami towarzyszą konflikty celów (Kivistö 2008). Teoria ta zakłada, że każda ze stron działa w interesie własnym, co w przypadku konfliktu interesów prowadzi do powstania tzw. ,problemu agencji”. Tam, gdzie agenci angażują się w zachowania egoistyczne, zleceniodawcy opracowują mechanizmy monitorowania działań agentów lub nagradzania ich, gdy spełniają określone wymagania. Będąc osobą z zewnątrz, zleceniodawca niemalże nie jest w stanie zrozumieć produktów agenta (Braun i Guston 2003: 303-304) - w naszym przypadku publikacji naukowych - ani ocenić ich wpływu na środowisko naukowe i społeczeństwo. Zgodnie z tym modelem zleceniodawca musi stosować „szereg inicjatyw nadzorczych, kompensacyjnych i karnych, aby dopilnować, by agent działał w najlepszym interesie zleceniodawcy” (Lane i Kivistö 2008: 145), czyli w najszerszym interesie publicznym - ujmowanym na różne sposoby, na przykład w ogólnym haśle rozwoju nauki.

W omawianym kontekście zleceniodawca ma obowiązek dopilnować, aby naukowcy prowadzili wysokiej jakości badania naukowe. Z tej perspektywy jakość badań naukowych prowadzonych za pośrednictwem dowolnych czasopism musiałaby zasadniczo podlegać weryfikacji - inaczej niż w przypadku czasopism najbardziej prestiżowych. Innymi słowy ponieważ zleceniodawcy zawsze szukają najmniej kosztownych i najskuteczniejszych sposobów nadzorowania agentów, łatwiej jest utożsamiać prestiżowe czasopisma z badaniami wysokiej jakości. Metryka publikacji w prestiżowych czasopismach pozwala zleceniodawcom na wszystkich szczeblach (krajowym, instytucjonalnym, wydziałowym) na obronę dokonywanej przez siebie dystrybucji nagród zarówno w systemach awansów akademickich, jak i w konkurencyjnym systemie finansowaniu badań ze środków publicznych.

Jako „mechanizm przesiewowy” w relacjach zleceniodawców z agentami, publikacje prestiżowe służą jako wspólna metryka osiągnięć we wszystkich dyscyplinach (Gomez-Mejia i Balkin 1992: 925); „zleceniodawca musi jedynie zliczać publikacje, które można uznać za publikacje wysokiej jakości. Natomiast jeśli wykorzystuje się całość publikacji, zleceniodawca musi poddać ocenie ich jakość, co wymaga ich przeczytania i zrozumienia - co jest z kolei procesem bardziej kosztownym i niepewnym" (Gomez-Mejia i Balkin 1992: 947). Ponadto publikowanie w prestiżowych czasopismach cieszy się szerokim konsensusem normatywnym w środowisku akademickim jako metryka osiągnięć, co ogranicza konflikty wewnętrzne.

Tradycyjna logika merytokracji w nauce oznacza, że przyjmuje się, iż w prestiżowej grze publikacyjnej niektórzy naukowcy z konieczności wygrywają, podczas gdy inni przegrywają. Publikacje w najlepszych czasopismach w danej dyscyplinie są dla wielu naukowców akademickich „odpowiednikiem gry w wielkich ligach sportowych lub występów w Carnegie Hall w dziedzinie sztuki. Podczas gdy wielu naukowców aspiruje do publikowania w najlepszych czasopismach, tylko niektórzy z nich realizują 
te aspiracje" (Fender i in. 2005: 93). Naukowcy się z tym godzą, co przyczynia się do spójności profesji akademickiej i nie rodzi niepotrzebnej i z pewnością konfliktującej - polaryzacji. Spójne zasady sprzyjają rozwojowi nauki - niespójne prowadzą do rozchwiania systemu, ponieważ nagradzani są nie ci, którzy powinni w ramach obowiązującej logiki merytokratycznej bazującej na poziomie (od zerowego do maksymalnego) wpływu na naukę, w ostatnich dekadach - coraz silniej na naukę globalną.

Ponieważ stratyfikacja społeczna w nauce i konkurencja (obok ciekawości naukowej) są najważniejszymi bodźcami napędzającymi akademickie badania naukowe, porównywanie osiągnięć na różnych poziomach zawsze było częścią etosu akademickiego (zob. moje wprowadzenie do zagadnień społecznej stratyfikacji w nauce w Kwiek 2020b). Metryka publikowania w czołowych czasopismach wspomaga zarówno zleceniodawców, jak i (nieco paradoksalnie) agentów w trwającej walce o uznanie naukowe i renomę akademicką (Marginson 2014; Kwiek 2019a). Dla poszczególnych naukowców i ich instytucji publikowanie w najlepszych czasopismach jest równoznaczne z odnoszeniem przez nich sukcesu. Jak tłumaczyli Heckman i Moktan, pięć najlepszych czasopism ekonomicznych (T5) wyznacza „standard branżowy”, a „spotkania wydziałowe dotyczące zatrudniania, awansowania, stażu pracy i dyskusje komitetów przyznających nagrody oceniają kandydatów na podstawie liczby artykułów z T5, które opublikowali lub przygotowują oraz szybkości, z jaką zostały opracowane” (2018: 4). Większość „inicjatyw na rzecz doskonałości" na całym świecie kieruje dodatkowe środki finansowe na badania do wybranych uczelni, potwierdzając wartość publikacji w najlepszych czasopismach dla zleceniodawców z różnych instytucji i dyscyplin, podczas gdy wartość innych publikacji pozostaje bez możliwości (prostego) potwierdzenia.

Badając rosnącą rolę elitarnych czasopism w powstawaniu i dystrybucji wiedzy akademickiej, teoria agencji oferuje użyteczny sposób postrzegania atrakcyjności tych czasopism, zarówno dla zleceniodawców (pod względem efektywności kosztowej, intuicyjnej sprawiedliwości i uproszczenia finansowania badań), jak i dla agentów, których sukces akademicki jest zdefiniowany i gwarantowany przez publikacje w najlepszych czasopismach. W przeciwieństwie do uważnej lektury wszystkich opublikowanych prac na potrzeby wydziałowej czy ogólnokrajowej eksperckiej oceny osiągnięć i wyników indywidualnych czy też instytucjonalnych, liczba publikacji w najlepszych czasopismach wymaga niewielkiego wysiłku monitorowania i oceny jakości (Heckman i Moktan 2018).

\section{3. Źródła danych i metodologia}

Koncentrując się na prestiżowych „generycznych”, a nie „tematycznych” (typu: jakość, marketing, kształcenie itp.) czasopismach poświęconych szkolnictwu wyższemu (Tight 2018), ważnym pytaniem jest kwestia ich wyboru. Spośród dwóch dostępnych 
opcji - lista oparta na subiektywnym postrzeganiu prestiżu (tj. ocena ekspercka) czy lista oparta na obiektywnych kryteriach bibliometrycznych (tj. cytowaniach) wybieramy tutaj tę drugą. Uwzględniając ostatnie propozycje Tight’a (2018), Horty (2018), Budda i Magnusona (2010) i innych, przyjęto tutaj następującą procedurę wyboru czasopism. Po pierwsze, w celu zdefiniowania czasopism podstawowych (core journals), w bazie danych Scopus stworzono listę wszystkich czasopism, których tytuł zawierał terminy higher education lub tertiary education (zob. Horta 2018; Jung i Horta 2013) oraz przeanalizowano ich główne parametry bibliometryczne. Scopus jest największą globalną bazą abstraktów i cytowań recenzowanych czasopism naukowych, książek i materiałów konferencyjnych, indeksującą 38060 czasopism naukowych (dane z grudnia 2019).

Scopus daje najlepszy przegląd struktury światowej nauki, w tym dostęp do większości czasopism znajdujących się w Web of Science firmy Clarivate, dawniej Thomson Reuters (Moya i in., 2007; Larivière i Sugimoto 2018). Tradycyjnie „najlepsze” czy „najbardziej prestiżowe” czasopisma w danej dziedzinie są definiowane jako najczęściej czytane lub najczęściej cytowane, a stosowane tu metryki bibliometryczne uwzględniają te kryteria. Dla celów niniejszego artykułu wybrano sześć elitarnych czasopism i przeanalizowano je w szerszym kontekście 41 czasopism podstawowych, które koncentrują się wyłącznie (a nie tylko „regularnie” czy „okazjonalnie”) (Tight 2018) na badaniach nad szkolnictwem wyższym. Wybrane czasopisma elitarne zajmują czołowe miejsca na liście 41 czasopism i znajdują się wśród najwyżej sklasyfikowanych czasopism „generycznych” z dziedziny badań szkolnictwa wyższego (patrz lista w tabeli 9, dane uzupełniające). Analizy przeprowadzono przy użyciu oprogramowania R, a do wizualizacji wykorzystano pakiet ggplot2.

Dane zostały pobrane z bazy Scopus w okresie 10-15 sierpnia 2019 roku. Łączna liczba uwzględnionych artykułów wyniosła 21442 (w tym 6334 z sześciu czasopism elitarnych). Metadane dla pobranych dokumentów zostały ograniczone pod względem etapu publikacji (tylko etap końcowy) i rodzaju publikacji (tylko artykuły). Metadane zawierały identyfikator autora, identyfikator dokumentu, afiliację instytucjonalną i krajową autorów oraz pełną bibliografię. Na kolejnym etapie metadane zostały pobrane dla wszystkich cytowań. Scopus przypisuje indywidualny numer identyfikacyjny każdemu dokumentowi oraz każdej osobie identyfikowanej w opisie danego dokumentu jako autor. Dla analizowanych dokumentów znaleziono 27878 unikalnych autorów. Ponieważ Scopus automatycznie łączy i agreguje dane dla pojedynczej osoby, nawet jeśli jej nazwisko jest zapisane inaczej, na przykład „Ziskin, M.”, „Ziskin, Mary B.” i „Ziskin, M.B.” mają ten sam Scopus ID - ostateczna lista objęła 26881 unikalnych autorów. Różne afiliacje w różnych krajach dla tej samej osoby mogą wskazywać na ich równoległe zatrudnienie lub mobilność w czasie w badanym okresie. W analizowanym zbiorze danych 1397 (lub 5,2\%) autorów z indywidualnym 
ID miało więcej niż jedną afiliację, co daje łącznie 3225 afiliacji. Zostały one usunięte z dalszych analiz dotyczących rozkładu afiliacji w czasie i według krajów.

Do analizy wybrano sześć czasopism: Higher Education (HE), Studies in Higher Education (SHE), Higher Education Research and Development (HERD), Journal of Higher Education (JHE), Research in Higher Education (ResHE) oraz Review of Higher Education (RevHE). Co ważne, wszystkie one pojawiały się w różnych konfiguracjach we wcześniejszych badaniach tego typu; jako trzy czołowe amerykańskie czasopisma, JHE, ResHE i RevHE były intensywnie analizowane w ostatnich dziesięcioleciach (Hutchinson i Lovell 2004; Budd i Magnuson 2010; Silverman 1987). Użyta tutaj lista opiera się na zaawansowanych pomiarach bibliometrycznych cytowań i związanego z nimi prestiżu w globalnym zbiorze danych, a mimo to jest identyczna z listami wykorzystywanymi we wcześniejszych opracowaniach w małej skali i w ujęciu przekrojowym, a nie longitudinalnym (np. w Tight 2014).

\section{Wyniki}

W badanym okresie lączna liczba artykułów opublikowanych w analizowanych sześciu czasopismach wyniosła 6334; a dwóch największych ich producentów, HE i SHE, odpowiadało za ponad połowę tej liczby (patrz tabela 1). W ciągu ostatnich dwóch dekad liczba artykułów publikowanych rocznie w sześciu czasopismach wzrosła prawie trzykrotnie, ze 100-150 rocznie w latach 1996-2000 do 400-470 rocznie w latach 2014-2018; całkowita liczba cytowań do artykułów z tych lat wyniosła 187 708. Trzy czasopisma odpowiadały za 71,31\% wszystkich cytowań: HE (ok. 53 000), SHE (ok. 43 500) i ResHE (ok. 37 ooo cytowań). Różnica między trzema najczęściej cytowanymi czasopismami a pozostałymi trzema nadal się powiększa (rys. 1). Jednakże, jak pokazuje wskaźnik CiteScore 2018, sześć czasopism uzyskuje zbliżoną liczbę cytowań w przeliczeniu na jeden artykuł; w 2018 roku HE uzyskało najwyższy wskaźnik CiteScore. (CiteScore wynoszący 10 oznacza, że artykuły opublikowane $\mathrm{w}$ danym czasopiśmie $\mathrm{w}$ ciągu trzech poprzednich lat otrzymały średnio 10 cytowań w roku bieżącym). Różnica w poziomie cytowań jest więc związana z rosnącą liczbą publikacji, a nie z hierarchią wśród sześciu czołowych czasopism. W szczególności w roku referencyjnym 2018 uwzględniono trzy parametry dotyczące cytowań (tabela 1): liczbę cytowań do artykułów opublikowanych w latach 1996-2018, poziom wpływu cytowań czasopisma (mierzony według CiteScore) oraz pozycję lub percentyl czasopisma (w dziedzinie „edukacja”, obejmującej 1038 czasopism). Zarówno wskaźnik CiteScore, jak i pozycja czasopisma wyrażona w percentylach są prostymi i przejrzystymi miernikami, które stanowią dobrą odpowiedź na krytykę współczynnika wpływu (impact factor) występującą w ostatnich dziesięcioleciach (zob. zarys krytyki w: Larivière i Sugimoto 2018). 
Tabela 1. Analiza przekrojowa - sześć elitarnych czasopism (wybrane miary Scopus, 2018)

\begin{tabular}{|l|c|c|c|c|c|c|}
\hline Journal & $\begin{array}{c}\text { Cite Score } \\
\mathbf{2 0 1 8}\end{array}$ & $\begin{array}{c}\text { Citations } \\
\mathbf{2 0 1 8}\end{array}$ & $\begin{array}{c}\text { Citations } \\
\mathbf{1 9 9 6 - 2 0 1 8}\end{array}$ & $\begin{array}{c}\text { Articles } \\
\mathbf{2 0 1 8}\end{array}$ & $\begin{array}{c}\text { Articles } \\
\mathbf{1 9 9 6}-\mathbf{2 0 1 8}\end{array}$ & $\begin{array}{c}\text { Highest percen- } \\
\text { tile (rank in Edu- } \\
\text { cation 2018) }\end{array}$ \\
\hline HE & 3.42 & 6759 & 53.038 & 122 & 1.946 & $95.0 \%(43 / 1038)$ \\
\hline SHE & 3.28 & 6239 & 43,358 & 155 & 1,465 & $95.0 \%(52 / 1038)$ \\
\hline HERD & 2.58 & 2985 & 18,293 & 99 & 1,039 & $91.0 \%(93 / 1038)$ \\
\hline JHE & 3.04 & 2792 & 23,590 & 24 & 529 & $93.0 \%(70 / 1038)$ \\
\hline ResHE & 2.97 & 3821 & 37,450 & 44 & 1,018 & $93.0 \%(72 / 1038)$ \\
\hline RevHE & 2.28 & 1361 & 11,979 & 25 & 337 & $86.0 \%(138 / 1038)$ \\
\hline Total & - & 23.957 & 187,708 & 469 & 6,334 & - \\
\hline
\end{tabular}

Zmieniająca się rola sześciu czasopism w czasie jest widoczna w zmieniającym się odsetku cytowań oraz odsetku opublikowanych dokumentów w porównaniu z pozostałymi czasopismami z naszej listy. W latach 1996-2018 znacznie spadł odsetek ich cytowań (z 69,18\% do 49,40\%) przy malejącym odsetku dokumentów (z 31,79\% do $27,52 \%)$. Zmiany te były jeszcze bardziej wyraźne w przypadku „wielkiej trójki” czasopism; podczas gdy ich odsetek cytowań spadł o 46,84\%, ich udział w liczbie artykułów spadł o 28,88\%. Rozkład cytowań w czasie wskazuje na rosnącą przepaść między coraz częściej cytowaną trójką (HE, SHE i ResHE) a pozostałymi trzema czołowymi czasopismami.

Rysunek 1. Liczba cytowań otrzymanych przez artykuły opublikowane w poszczególnych czasopismach i latach (baza Scopus 1996-2018)

$$
\begin{array}{lll}
\text { HE } & \text { HE HERD } \cdots & \text { ResHE } \\
--- \text { SHE - JHE } & \text { RevHE }
\end{array}
$$

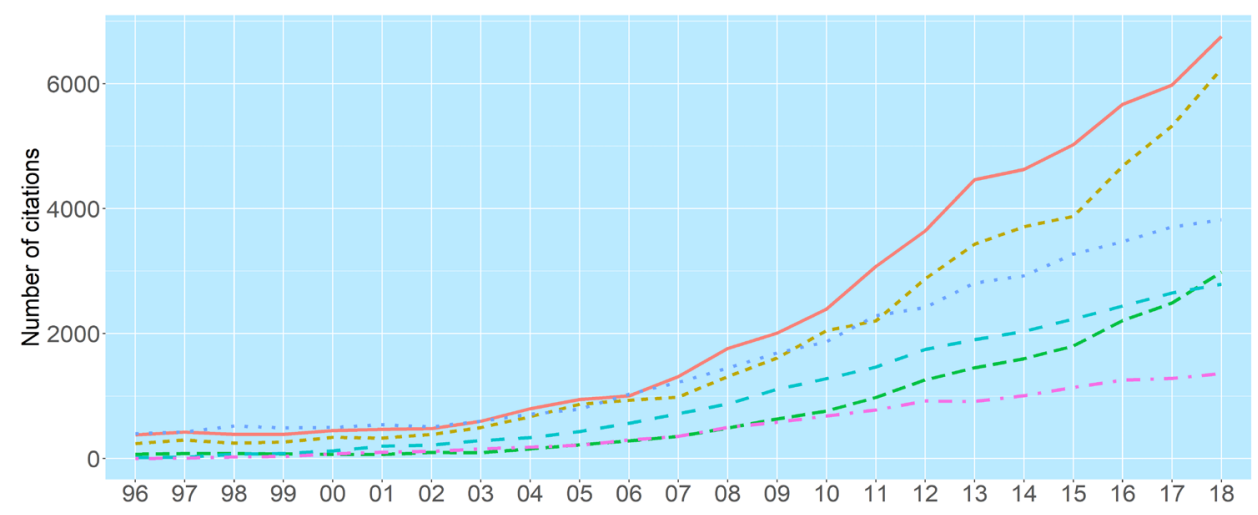

Wskaźnik Herfindahla-Hirschmana (HHI) ujawnia malejącą rolę czasopism elitarnych jako źródeł cytowań w dziedzinie badań nad szkolnictwem wyższym. 
Ten wskaźnik koncentracji rynku, stosowany w analizie antymonopolowej i prawie dotyczącym konkurencji (Laine 1995), jest obliczany jako suma kwadratów udziału w rynku wszystkich firm na danym rynku i może wahać się od o dla rynku wysoce konkurencyjnego do 10000 (co odpowiada 100\%) dla rynku czysto monopolowego. W analizowanym przypadku wskaźnik HHI odnosi się do koncentracji czasopism i cytowań do ich artykułów dla próby 41 głównych czasopism. Zmieniający się w czasie poziom wskaźnika HHI odzwierciedla zmiany w koncentracji cytowań do artykułów z czasopism podstawowych. Przyjmując każde czasopismo jako oddzielną jednostkę, analiza wskazuje, że w ciągu ostatniego ćwierćwiecza koncentracja znacznie spadła (ze wskaźnika HHI wynoszącego ok. 1600 do ok. 1000). Jeżeli sześć elitarnych czasopism potraktować jako jedną jednostkę, to koncentracja maleje jeszcze bardziej (z ok. 5000 do ok. 3000). Zmiany te potwierdzają, że rynek cytowań czasopism szkolnictwa wyższego staje się mniej skoncentrowany, a rola sześciu czasopism na tym rynku maleje. Jednak mimo znacznego osłabienia monopolu cytowań czołowych czasopism (Larivière i in. 2014), jak wspominaliśmy w części teoretycznej, ich rola jest ważniejsza niż kiedykolwiek wcześniej jeśli chodzi o awans akademicki i poziom wynagrodzeń to temat, do którego jeszcze powrócimy.

Tabela 2. Wskaźnik Herfindahla-Hirschmana (HHI) w latach 1996-2018 - koncentracja cytowań dla czasopism naukowych z obszaru badań szkolnictwa wyższego

Objaśnienie: HHI (1) odnosi się do każdego czasopisma traktowanego jako odrębna jednostka (w sumie 41 jednostek); HHI (2) odnosi się do sześciu elitarnych czasopism traktowanych jako jedna jednostka (w sumie 36 jednostek).

\begin{tabular}{|c|c|c|c|c|c|c|c|c|}
\hline Year & HHI (1) & HHI (2) & Year & HHI (1) & HHI (2) & Year & HHI (1) & HHI (2) \\
\hline 1996 & 1596 & 4934 & 2004 & 1314 & 4324 & 2012 & 1013 & 3359 \\
\hline 1997 & 1616 & 5012 & 2005 & 1255 & 3942 & 2013 & 966 & 3049 \\
\hline 1998 & 1527 & 4973 & 2006 & 1131 & 3695 & 2014 & 1008 & 3206 \\
\hline 1999 & 1492 & 4885 & 2007 & 1054 & 3664 & 2015 & 956 & 3105 \\
\hline 2000 & 1353 & 4264 & 2008 & 1042 & 3563 & 2016 & 982 & 3113 \\
\hline 2001 & 1290 & 4287 & 2009 & 1006 & 3401 & 2017 & 991 & 3064 \\
\hline 2002 & 1217 & 3967 & 2010 & 996 & 3231 & 2018 & 997 & 3006 \\
\hline 2003 & 1251 & 4139 & 2011 & 964 & 3311 & & & \\
\hline
\end{tabular}

\subsection{Stratyfikacja globalnej społeczności badaczy szkolnictwa wyższego - "pełnoetatowcy" $i$ „niepełnoetatowcy”}

Poniżej analizujemy stratyfikację globalnego środowiska badaczy szkolnictwa wyższego mierzoną za pomocą liczby artykułów opublikowanych w sześciu elitarnych i 41 podstawowych czasopismach z okresu 1996-2018, w oparciu o wszystkie publikacje (jako autor lub współautor), a nie w ujęciu publikacji o autorstwie frakcjonowanym, czyli dzielonym przez liczbę autorów. Łącznie 8226 naukowców było w tym 
okresie autorami lub współautorami co najmniej jednej pracy w sześciu elitarnych czasopismach. Liczba autorów co najmniej pięciu prac w elitarnych czasopismach naszych autorów „pełnoetatowych” - wynosiła 274 (lub 3,3\% wszystkich autorów posiadających indywidualne ID autorów Scopus) (zob. tabela 3). Łączna liczba badaczy akademickich związanych z 21442 artykułami w 41 podstawowych czasopismach wyniosła 26881 , z czego 878 (3,3\%) to pełnoetatowcy. Większość z tych, którzy pisali w sześciu elitarnych czasopismach (6 485 lub 78,8\%), opublikowała tylko jeden artykuł - innymi słowy, byli to nasi „niepełnoetatowcy” - podczas gdy pełnoetatowcy, którzy byli autorami lub współautorami co najmniej pięciu artykułów, byli jednym na trzydziestu autorów. W 41 podstawowych czasopismach 21389 (79,6\%) autorów opublikowało tylko jeden artykuł (w prezentowanym ujęciu 41 czasopism podstawowych obejmuje również 6 czasopism elitarnych jako swoją podgrupę).

Tabela 3. Analiza przekrojowa - rozkład produktywności autorów (na podstawie Scopus Author IDs) pod względem liczby publikacji w czasopismach elitarnych i podstawowych dotyczących badań szkolnictwa wyższego (1996-2018) (częstość i procent)

\begin{tabular}{|c|c|c|c|c|}
\hline \multirow{2}{*}{$\begin{array}{l}\text { Articles per } \\
\text { author }\end{array}$} & \multicolumn{2}{|c|}{6 elite journals } & \multicolumn{2}{|c|}{41 core journals } \\
\hline & $\mathbf{N}$ & $\begin{array}{c}\text { Cumulative } \\
\%\end{array}$ & $\mathbf{N}$ & $\begin{array}{c}\text { Cumulative } \\
\%\end{array}$ \\
\hline 20 and more & 7 & 0.1 & 25 & 0.1 \\
\hline 10 & 66 & 0.8 & 185 & 0.7 \\
\hline 5 & 274 & 3.3 & 878 & 3.3 \\
\hline 4 & 439 & $5 \cdot 3$ & 1354 & 5.1 \\
\hline 3 & 744 & 9.0 & 2328 & 8.7 \\
\hline 2 & 1741 & 21.2 & 5492 & 20.5 \\
\hline 1 & 8226 & 100.0 & 26881 & 100.0 \\
\hline Total & 8226 & 100.0 & 26881 & 100.0 \\
\hline
\end{tabular}

Analiza krajowych afiliacji autorskich wskazuje, że spośród tych, którzy publikowali w czasopismach elitarnych (rysunek 2), pełnoetatowcy pochodzili z trzech klastrów krajów: USA (30,2\%), innych krajów anglosaskich (43\%) i najważniejszych systemów europejskich (w kolejności malejącej liczby artykułów: Holandia, Hiszpania, Finlandia, Niemcy, Szwecja, Norwegia, Portugalia, Belgia, Włochy, Dania). W klastrze wszystkich pozostałych krajów udział pełnoetatowców wyniósł 5,5\%. Udział niepełnoetatowców był nieco wyższy w przypadku USA i niższy w pozostałych krajach, choć klaster wszystkich pozostałych krajów zwiększył swój udział do 11,6\%. W przypadku 41 podstawowych czasopism (rysunek 3), czyli globalnej społeczności badaczy szkolnictwa wyższego, struktura jest podobna do struktury dla segmentu elitarnego, z wyjątkiem USA, gdzie udział pełnoetatowców wzrósł o jedną trzecią (do 37,8\%), oraz innych krajów anglosaskich, gdzie ich udział spadł o prawie 10\%. Dla klastra krajów Azji 
Wschodniej, głównych krajów europejskich i wszystkich „innych” krajów, proporcje etatowców i niepełnoetatowców w obu zestawach czasopism były podobne.

Rysunek 2. Pełnoetatowy (autorzy 5 opublikowanych prac) i niepelnoetatowcy (autorzy tylko 1 opublikowanej pracy) w 6 czasopismach elitarnych (1996-2018) w podziale na grupy krajów (\%)

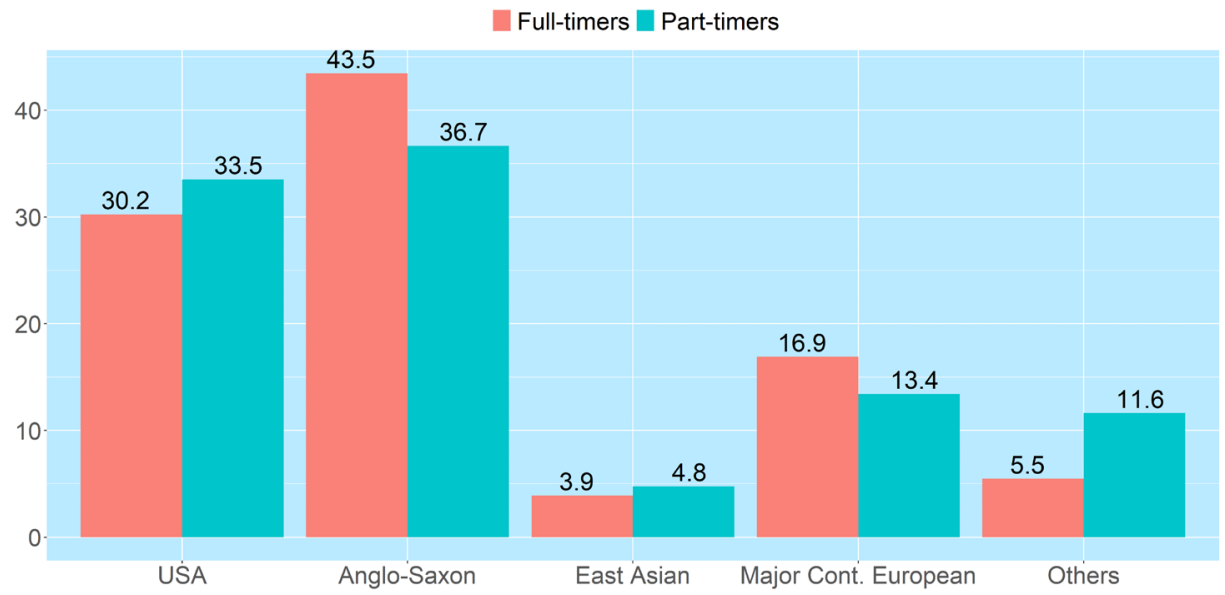

Rysunek 3. Pełnoetatowy (autorzy 5 opublikowanych prac) i niepełnoetatowcy (autorzy tylko 1 opublikowanej pracy) w 41 podstawowych czasopismach (1996-2018) $\mathrm{w}$ podziale na grupy krajów (\%)

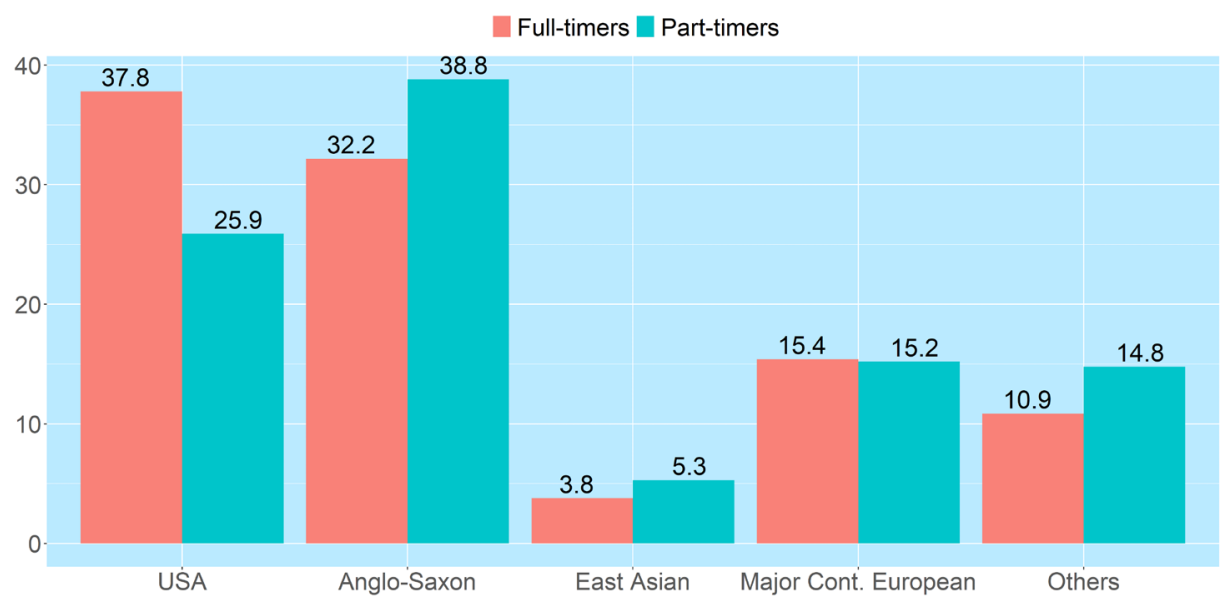

Dla artykułów z sześciu elitarnych czasopism jądrowy estymator gęstości rozkładu cytowań (estimated kernel density: rodzaj estymatora nieparametrycznego, przeznaczonego do wyznaczania gęstości rozkładu zmiennej losowej na podstawie uzyskanej 
próby) jest krzywą względnie standardową. Większość artykułów uzyskała mniej niż 25 cytowań, podczas gdy ich ograniczona liczba uzyskała 100 cytowań lub więcej (zob. rysunek 4). HERD wykazywało najbardziej nierównomierny rozkład cytowań: duża liczba artykułów miała bardzo niski poziom cytowań. Z perspektywy interdyscyplinarnej potencjał cytowań w elitarnych czasopismach badaczy szkolnictwa wyższego jest stosunkowo niski, jeśli spojrzeć na nie przez pryzmat bibliometryczny. Wskaźnik CiteScore umożliwia użyteczne porównania między dyscyplinami (tzn. wpływ czasopisma jako średnia liczba cytowań w przeliczeniu na dokument). O ile w 2018 r. CiteScore dla sześciu najlepszych czasopism szkolnictwa wyższego mieścił się w przedziale 2,28-3,42, o tyle w przypadku dziesięciu najlepszych czasopism z innych dziedzin nauk społecznych był on na ogół wyższy (komunikacja: 3.82-5.92, prawo: 4.09-7.1, administracja publiczna: 3.22-8.42, socjologia i nauki polityczne: 6.23-10.13 oraz edukacja: 5.45-12.31; dziesięć najlepszych czasopism z zakresu nauk przyrodniczych uzyskuje rzecz jasna znacznie wyższy poziom CiteScore, np. biochemia: 18.73-25.59, inżynieria chemiczna: 13.5-29.72).

Rysunek 4. Jądrowy estymator gęstości - rozkład cytowań dla artykułów z 6 czasopism elitarnych, liczba cytowań na osi poziomej, 100 oznacza 100 i więcej (według czasopism,
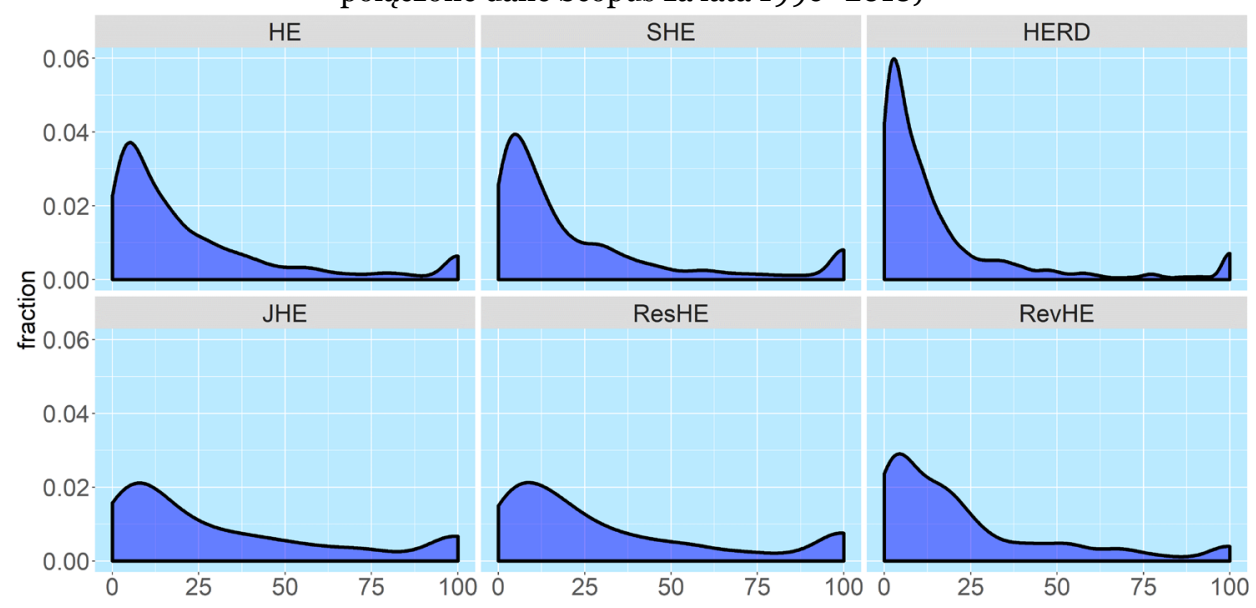

Objaśnienie: powierzchnia pod krzywą skalowania wynosi 1. Estymator oparty na jądrze gaussowskim (normalnym) i szerokości pasma 2 (wizualizacja).

\subsection{Zmieniająca się geografia afiliacji autorskich według krajów w sześciu czasopismach elitarnych}

W oparciu o afiliacje autorskie według krajów, w tej części pracy przeanalizowano następujące pytania: Jak „międzynarodowe” są czasopisma z obszaru badań szkolnictwa wyższego tradycyjnie uważane za „międzynarodowe”? Jak „krajowe” są amerykańskie 
czasopisma tradycyjnie uważane za „krajowe”? W jaki sposób zmieniały się w czasie ich profile pod względem kraju pochodzenia autorów?

\subsubsection{Analiza przekrojowa}

Jeśli chodzi o wzorce autorstwa publikacji, w istniejącej literaturze rozróżnia się głównie elitarne czasopisma „krajowe” (tutaj: krajowe amerykańskie, szeroko czytane w świecie) i „globalne" (międzynarodowe). Produkcja wiedzy w elitarnych czasopismach poświęconych szkolnictwu wyższemu jest silnie skoncentrowana geograficznie (zob. tabela 4), a w latach 1996-2018 jej rozkład w 91 krajach wnoszących wkład do analizowanej dziedziny był silnie asymetryczny. Dziesięć pierwszych krajów w zbiorze danych odpowiadało za $81,80 \%$ wszystkich afiliacji, a 25 pierwszych krajów - za $95,2 \%$. W tym samym okresie pozostałe 66 krajów reprezentowało zaledwie 4,8\% wszystkich afiliacji.

Geografia badań szkolnictwa wyższego prezentowanych w elitarnych czasopismach (a nie wszystkich badań, co jest ważnym ograniczeniem) wyraźnie pokazuje różnice między Stanami Zjednoczonymi, innymi krajami anglosaskimi i resztą świata. Hegemoniczna pozycja trzech największych anglosaskich uczestników elitarnych badań nad szkolnictwem wyższym (USA, Australii i Wielkiej Brytanii) nie jest zaskakująca, odpowiadają one za 63,7\% wszystkich afiliacji. Pozostałe trzy (Kanada, Irlandia i Nowa Zelandia) reprezentują 9,0\% afiliacji, a dalsze 4,6\% przypada na inne kraje anglojęzyczne, takie jak Republika Południowej Afryki, Hongkong i Singapur. W sumie kraje anglosaskie odpowiadają za ponad trzy czwarte wszystkich afiliacji (77,3\%). Tight (2014) przeanalizował kraje pochodzenia pierwszych autorów 273 artykułów opublikowanych w 2010 r.; natomiast w niniejszym studium zastosowano inną skalę - przeanalizowano wszystkie afiliacje wszystkich autorów 6334 artykułów opublikowanych w sześciu czasopismach latach 1996-2018 oraz szerszy kontekst (21 442 artykuły).

Tabela 5 wskazuje, że podczas gdy dwa czasopisma (RevHE i JHE) reprezentowały w latach 1996-2018 (łącznie) 1,6-2\% afiliacji nieamerykańskich i nieanglosaskich, ResHE reprezentowało ich znacznie więcej (9,3\%). W przypadku JHE i RevHE udział afiliacji autorów amerykańskich wynosił około 95-97\%, podczas gdy w przypadku ResHE był on niższy (85,4\%). W tym sensie JHE, ResHE i RevHE są wyraźnie krajowymi czasopismami (w tym przypadku: amerykańskimi). Trzy pozostałe z sześciu najlepszych czasopism (HE, SHE i HERD) różnią się znacznie pod względem odsetka afiliacji nieanglojęzycznych, wahającym się od 19 do 54\%. W samym tylko HE ponad połowa wszystkich autorów (54,2\%) miała afiliacje nieanglosaskie; dla SHE wskaźnik ten wyniósł $36,7 \%$, a dla HERD - 18,9\%. HE miało nieco wyższy udział (13,7\%) w afiliacjach amerykańskich. Oprócz nowatorskiej analizy przekrojowej całego okresu 1996-2018 łącznie, analiza longitudinalna prezentowana w następnej części pracy ukazuje zmiany profilu czasopism w dłuższym okresie czasu (niezależnie od zmiany składu ich redakcji czy ich rad redakcyjnych). 
Oprócz afiliacji anglosaskich, w elitarnych czasopismach wyróżniały się dwa regiony świata odpowiadające w sumie za około 21,8\% afiliacji w latach 1996-2018: największe kraje kontynentalnej Europy (16,7\%) i Azji Wschodniej (w tym Chiny, Hongkong, Japonia, Korea Południowa, Malezja, Singapur i Tajwan) (5,1\%). Wkład wszystkich pozostałych krajów był niewielki, jednak znaczący $(8,2 \%)$.

Tabela 4. Analiza przekrojowa - 25 najważniejszych afiliacji autorów artykułów opublikowanych w 6 elitarnych czasopismach według kraju (łączne dane Scopus za lata 1996-2018) dla 91 krajów (afiliacje nieustalone pod względem kraju zostały usunięte z analizy)

\begin{tabular}{|r|l|r|r|r|l|r|r|}
\hline \multicolumn{1}{|c|}{ Rank } & \multicolumn{1}{c|}{ Country } & \multicolumn{1}{c|}{ N } & \multicolumn{1}{c|}{ \% } & \multicolumn{1}{c|}{ Rank } & \multicolumn{1}{l|}{ Country } & \multicolumn{1}{c|}{ N } & \multicolumn{1}{c|}{ \% } \\
\hline 1 & United States & 3,587 & 30.7 & 15 & Belgium & 131 & 1.1 \\
\hline 2 & Australia & 2,216 & 19.0 & 16 & China & 123 & 1.1 \\
\hline 3 & United Kingdom & 1,568 & 13.4 & 17 & Italy & 104 & 0.9 \\
\hline 4 & Netherlands & 436 & 3.7 & 18 & Denmark & 85 & 0.7 \\
\hline 5 & lanada & 402 & 3.4 & 19 & Malaysia & 82 & 0.7 \\
\hline 6 & New Zealand & 352 & 3.0 & 20 & South Korea & 77 & 0.7 \\
\hline 7 & South Africa & 304 & 2.6 & 21 & Taiwan & 74 & 0.6 \\
\hline 8 & Spain & 269 & 2.3 & 22 & Israel & 66 & 0.6 \\
\hline 9 & Finland & 217 & 1.9 & 23 & Ireland & 61 & 0.5 \\
\hline 10 & Germany & 214 & 1.8 & 24 & Japan & 51 & 0.4 \\
\hline 11 & Sweden & 200 & 1.7 & 25 & Singapore & 45 & 0.4 \\
\hline 12 & Hong Kong & 185 & 1.6 & $\begin{array}{l}\text { Subtotal affiliations } \\
\text { from top 25 countries }\end{array}$ & 11,131 & 95.2 \\
\hline 13 & Norway & 141 & 1.2 & $\begin{array}{l}\text { Subtotal affiliations } \\
\text { from 66 other countries }\end{array}$ & 557 & 4.8 \\
\hline 14 & Portugal & 141 & 1.2 & Total affiliations & 11,688 & 100 \\
\hline
\end{tabular}

Tabela 5. Analiza przekrojowa - najważniejsze afiliacje autorów w artykułach publikowanych w 6 elitarnych czasopismach w podziale na kraje, klastry krajów i czasopisma (łączne dane Scopus za lata 1996-2018)

\begin{tabular}{|c|c|c|c|c|c|c|c|c|c|c|c|c|c|c|}
\hline \multirow{2}{*}{ Cluster } & \multicolumn{2}{|c|}{ HE } & \multicolumn{2}{|c|}{ SHE } & \multicolumn{2}{|c|}{ HERD } & \multicolumn{2}{|c|}{ JHE } & \multicolumn{2}{|c|}{ ResHE } & \multicolumn{2}{|c|}{ RevHE } & \multicolumn{2}{|c|}{ Total } \\
\hline & $\mathbf{N}$ & $\%$ & $\mathbf{N}$ & $\%$ & $\mathbf{N}$ & $\%$ & $\mathbf{N}$ & $\%$ & $\mathbf{N}$ & $\%$ & $\mathbf{N}$ & $\%$ & $\mathbf{N}$ & $\%$ \\
\hline USA & 456 & 13.7 & 224 & 5 & 97 & 4.3 & 836 & 94.7 & 1428 & 85.4 & 546 & 96.8 & 3587 & 30.7 \\
\hline $\begin{array}{l}\text { Anglo- } \\
\text {-Saxon }\end{array}$ & 1066 & 32.1 & 1666 & 55.8 & 1740 & 76.8 & 29 & $3 \cdot 3$ & 89 & $5 \cdot 3$ & 9 & 1.6 & 4599 & 39.3 \\
\hline Major & 1001 & 30.2 & 648 & 21.7 & 202 & 8.9 & 11 & 1.2 & 87 & 5.2 & 0 & 0.0 & 1949 & 16.7 \\
\hline East Asian & 279 & 8.4 & 186 & 6.2 & 88 & 3.9 & 3 & 0.3 & 32 & 1.9 & 4 & 0.7 & 592 & 5.1 \\
\hline Other & 517 & 15.6 & 259 & 8.7 & 140 & 6.2 & 4 & 0.5 & 36 & 2.2 & 5 & 0.9 & 961 & 8.2 \\
\hline Total & 3319 & 100 & 2983 & 100 & 2267 & 100 & 883 & 100 & 1672 & 100 & 564 & 100 & 11688 & 100 \\
\hline
\end{tabular}

Aby ocenić zmieniającą się w czasie koncentrację afiliacji autorów z poszczególnych krajów, warto ponownie odwołać się do wskaźnika HHI. Jego spadek o prawie 
połowę (z 2207 do 1166) wyraźnie wskazuje na postępującą dekoncentrację afiliacji autorskich w elitarnych czasopismach w latach 1996-2018 (tabela 6); innymi słowy, wcześniejszy monopol geograficzny ulega znacznemu osłabieniu.

Tabela 6. Wskaźnik Herfindahla-Hirschmana (HHI) - koncentracja afiliacji autorskich według kraju (41 czasopism, 125 afiliacji) w ujęciu rocznym, 1996-2018

\begin{tabular}{|l|l|l|l|l|l|l|l|l|l|}
\hline Year & HHI & Year & HHI & Year & HHI & Year & HHI & Year & HHI \\
\hline 1996 & 2207 & 2001 & 1970 & 2006 & 1849 & 2011 & 1683 & 2016 & 1329 \\
\hline 1997 & 2509 & 2002 & 2246 & 2007 & 2185 & 2012 & 1806 & 2017 & 1236 \\
\hline 1998 & 2472 & 2003 & 1978 & 2008 & 1779 & 2013 & 1561 & 2018 & 1166 \\
\hline 1999 & 2448 & 2004 & 2141 & 2009 & 1958 & 2014 & 1616 & & \\
\hline 2000 & 2604 & 2005 & 2299 & 2010 & 1743 & 2015 & 1432 & & \\
\hline
\end{tabular}

4.2.2. Analiza podłużna (longitudinalna)

Według naszej najlepszej wiedzy nie analizowano dotąd szczegółowo zmieniających się wzorców afiliacji autorstwa we wszystkich sześciu elitarnych czasopismach (lub w którymkolwiek z nich) na przestrzeni czasu - czyli w ujęciu podłużnym (longitudinalnym). Biorąc pod uwagę globalną ekspansję szkolnictwa wyższego, interesujące jest zbadanie zmieniającej się roli najważniejszych krajów Europy kontynentalnej i Azji Wschodniej oraz postawienie pytania, czy radykalny wzrost liczby publikacji wydanych w elitarnych czasopismach (ze 154 w 1996 r. do 469 w 2018 r.) jest napędzany przez nowicjuszy w badanej dziedzinie „szybko nadrabiających zaległości” (Tight 2014: 16), czy też przez USA i kraje anglosaskie, tradycyjnych hegemonów.

Zmieniające się wzorce autorstwa w trzech kolejnych okresach (1996-2003, 2004-2011 i 2012-2018) zostały szczegółowo przeanalizowane w czasie pod względem afiliacji i ich częstości występowania. Tabela 7 (dane uzupełniające na końcu tekstu) pokazuje szczegółowo, że łączny udział wszystkich afiliacji anglosaskich maleje, a udział głównych afiliacji z Europy kontynentalnej i Azji Wschodniej oraz wszystkich „innych” afiliacji szybko rośnie. W nowej geografii elitarnych badań szkolnictwa wyższego, relatywnie nowi przybysze zyskują kosztem krajów tradycyjnie dominujących, których obecność maleje. Największym przegranym pod kątem afiliacji (analizę rozkładu cytowań w czasie pozostawiamy na inną okazję) są Stany Zjednoczone, z 42,5\% afiliacji w publikacjach w latach 1996-2003 spadającymi do tylko 26,9\% afiliacji w latach 2012-2018. Stanowi to odzwierciedlenie zarówno rosnącego udziału afiliacji nieamerykańskich w ogóle, jak i rosnącego z roku na rok wolumenu publikacji w HE i SHE (rys. 6), w których amerykańscy naukowcy na ogół nie publikują (rys. 5, pierwszy panel). Największy wzrost, do niemal 20\% (19,3\%) wszystkich afiliacji w latach 2012-2018, nastąpił w Australii, z 15,3\% w latach 1996-2003. Jednak sumarycznie 
odsetek wszystkich afiliacji anglosaskich spadł z 80,8\% w latach 1996-2003 do 66,3\%. Głównym wygranym jest Europa kontynentalna, która zanotowała prawie dwukrotny wzrost udziału (z 9,7 do 18,3\%), przy bardzo dużej widoczności autorów europejskich w HE i SHE. Zwiększył się również udział najważniejszych afiliacji z Azji Wschodniej (z 3,9\% do 5,9\%), głównie w HE i SHE. Prawdopodobnie najbardziej interesującym zjawiskiem jest jednak stały wzrost wszystkich ,innych” afiliacji, spoza trzech głównych klastrów globalnych (z 5,6 do 9,5\%), przy czym dominuje ponownie HE. Do grupy nowych krajów należą: Izrael, Chile, Turcja, Iran, Szwajcaria i Polska.

Jeśli natomiast chodzi o zmieniającą się w czasie liczbę afiliacji (a nie ich odsetek, rysunki 6 i 7, tabela 8), dane dotyczące czasopism elitarnych są jeszcze bardziej wymowne, być może odzwierciedlając nowe wzorce współpracy w globalnych badaniach nad szkolnictwem wyższym (globalne wzorce współpracy naukowej, zob. Kwiek 2019c i Kwiek 2020a; predyktory współpracy międzynarodowej w Europie, zob. Kwiek 2015b). Między pierwszym okresem (1996-2003) a okresem trzecim (2012-2018) liczba artykułów z afiliacjami amerykańskimi wzrosła trzykrotnie. Jednak dla Australii wzrosła ona sześciokrotnie, dla głównych systemów europejskich łącznie - ośmiokrotnie, dla Azji Wschodniej siedmiokrotnie, a dla wszystkich „innych” krajów - ośmiokrotnie (tabela 8). W trzecim analizowanym okresie (2012-2018) odnotowano około 1800 afiliacji amerykańskich, 1500 europejskich, 400 wschodnioazjatyckich i 650 z „innych” krajów. Dla porównania, w pierwszym analizowanym okresie (1996-2003) dla USA było ich 641 w porównaniu ze 146, 59 i 85 odpowiednio dla pozostałych grup krajów. Zmiany są znaczące i niosą z sobą daleko idące konsekwencje - za przetasowaniami czysto geograficznymi mogą z czasem pojawić się przetasowania teoretyczne (zob. analizę niedopasowania koncepcji amerykańskich do europejskich systemów wynagrodzeń akademickich w Kwiek 2018a). Wzrost liczby publikacji pomiędzy tymi dwoma okresami był nadzwyczajny w kilku krajach europejskich, w tym w Portugalii (od o do 100 afiliacji), Belgii (od 2 do 90), Danii (od 1 do 72), Hiszpanii (od 13 do 178) i w Niemczech (od 6 do 168).

W trzech nieamerykańskich czasopismach elitarnych (HE, SHE i HERD) odsetek publikacji z afiliacjami amerykańskimi w całym analizowanym okresie był niski i generalnie malał, podczas gdy odsetek innych anglosaskich afiliacji był umiarkowany i malał (HE) lub też był wysoki i malał (SHE i HERD) (rysunek 5). W ujęciu liczbowym (rysunek 7) systematycznie rośnie liczba publikacji z afiliacjami anglosaskimi (SHE i HERD) oraz z afiliacjami z kontynentalnej Europy (HE, SHE i HERD). W Azji Wschodniej analizowana dziedzina rośnie w Chinach, Korei Południowej, Malezji i Hongkongu (choć w tym ostatnim kraju odnotowano spadek wzrostu), podczas gdy Japonia w badaniach szkolnictwa wyższego (prezentowanych w elitarnych czasopismach) nadal odgrywa marginalną rolę. Analogicznie zmiany w ujęciu longitudinalnym (podłużnym) można przedstawić dla 41 podstawowych czasopism, jednak wyników nie pokazujemy z powodu ograniczonego miejsca. 


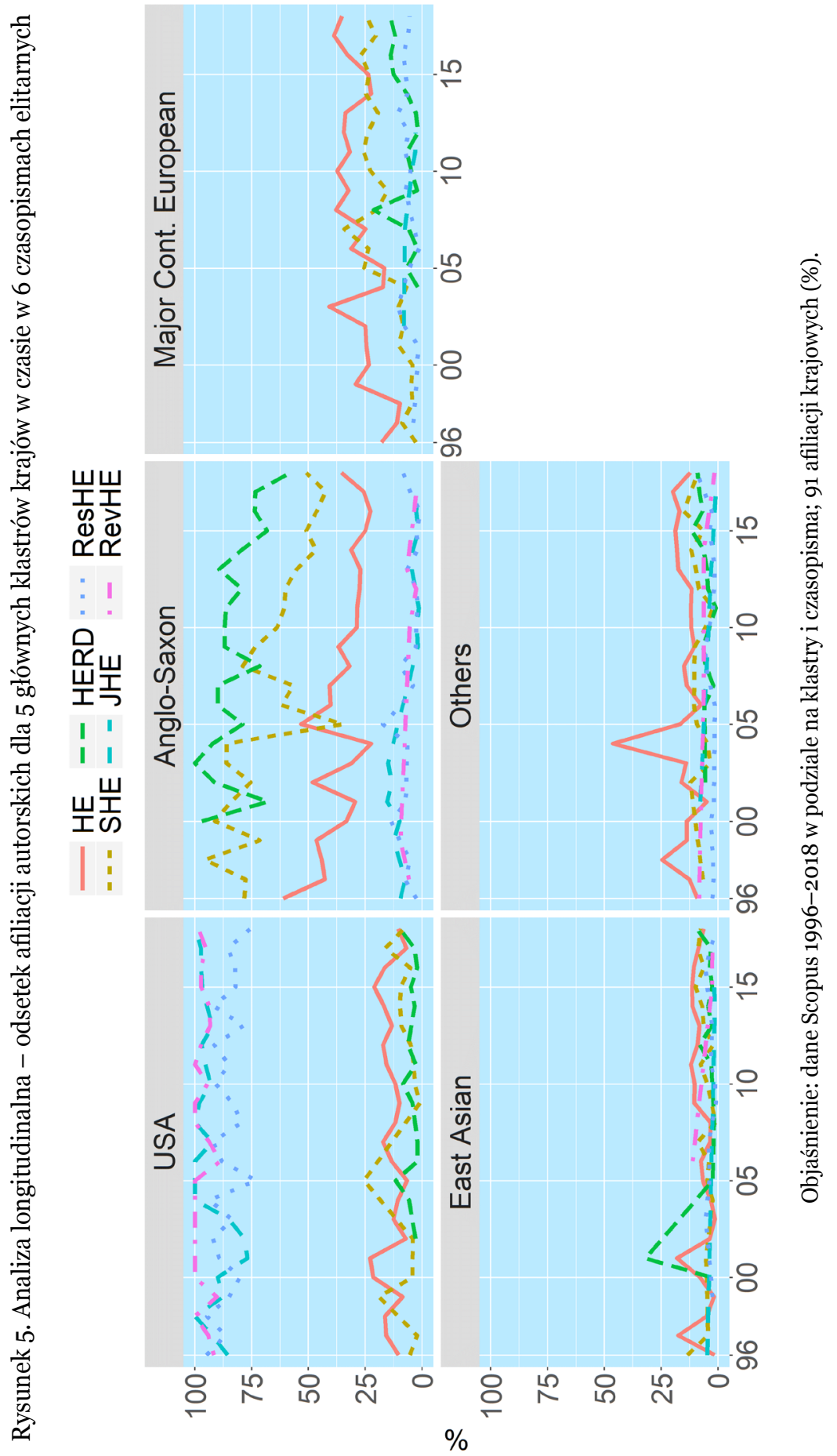




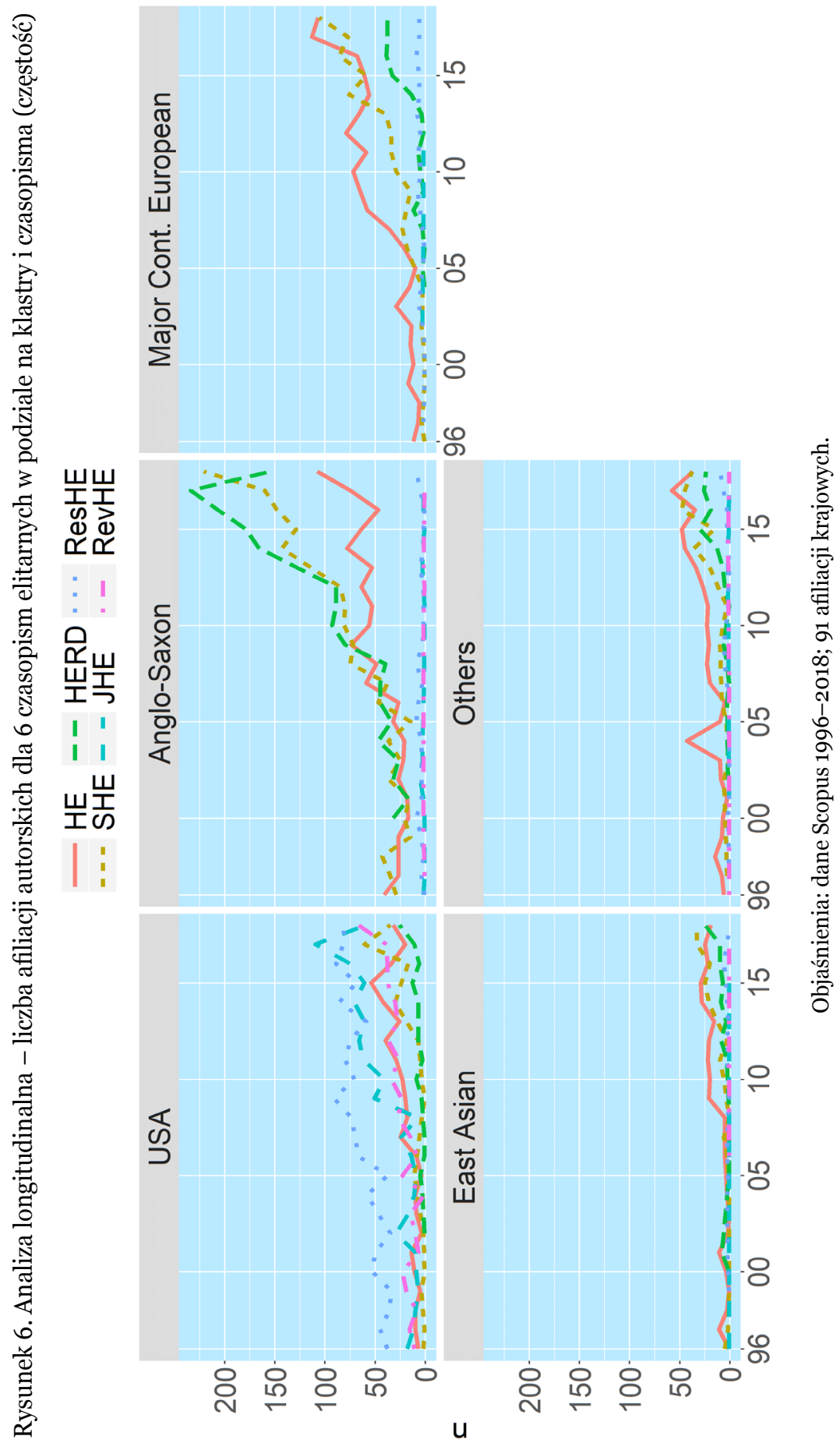




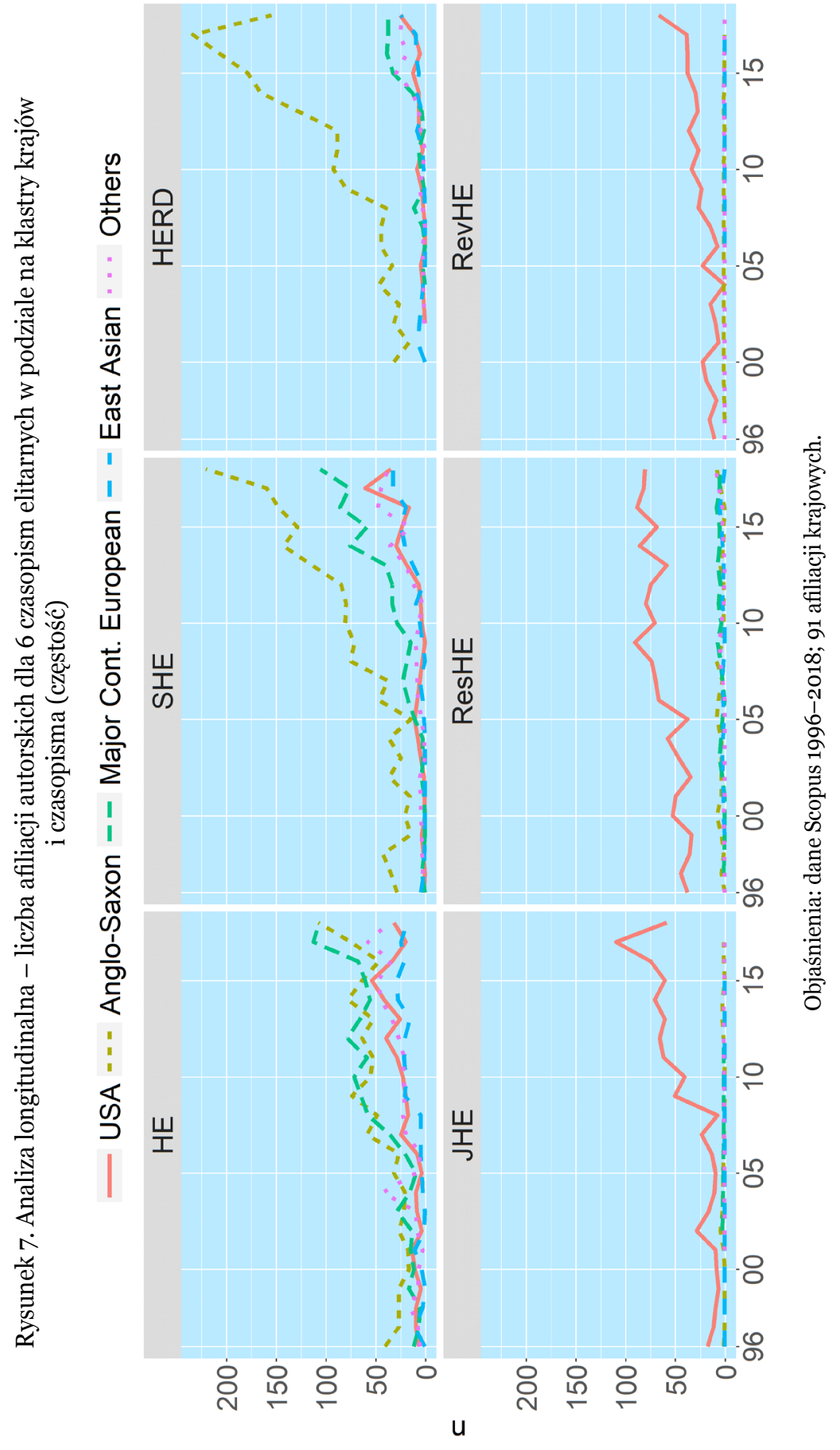




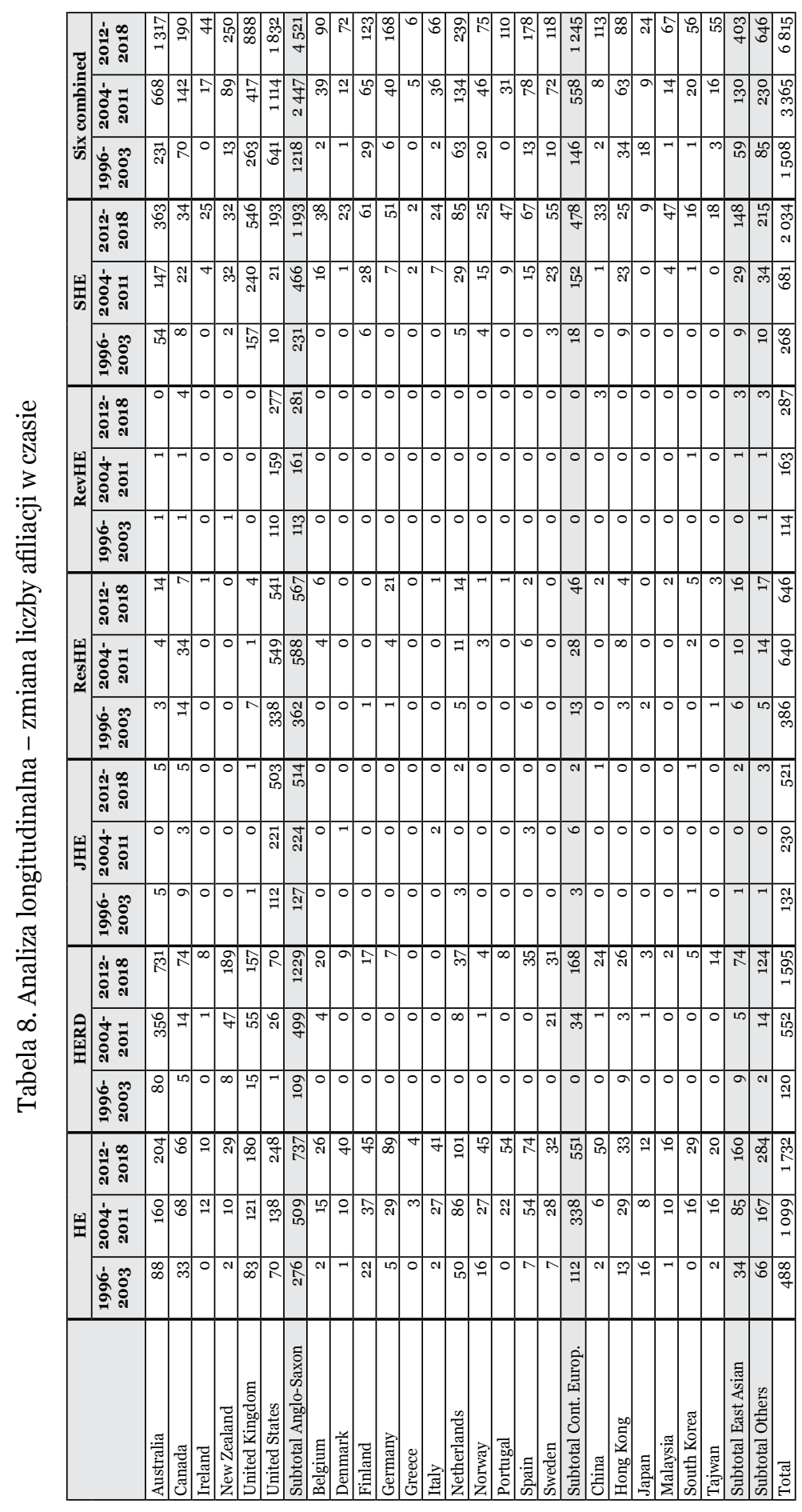

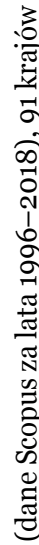

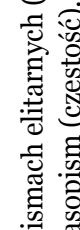

ठิ సู

疋

马

w

प्山

3

范

㝴

吾芯

造

3

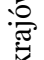

b

营

.

营

च

:

$\ddot{\theta}$

.

: 


\section{Dyskusja i wnioski}

Rozkład cytowań jest specyficzny dla poszczególnych dziedzin (Moed 2005); podczas gdy publikacje w niektórych z nich są silnie cytowane, w innych są cytowane znacznie słabiej (Sugimoto i Larivière 2018: 69-76), dlatego wszelkie porównania wymagają normalizacji do dziedziny. W obszarze badań nad szkolnictwem wyższym jego ekspansja i kurczenie się w różnych krajach ma znaczący wpływ na wzorce cytowania, podobnie jak ogólna liczba aktywnych naukowców w tej dziedzinie, ich globalny rozkład według krajów, ich preferowany język badań oraz ich indywidualne wzorce publikacyjne ( $w$ tym preferencje dla krajowych bądź globalnych rynków publikacyjnych, zob. analizę najbardziej produktywnych 10\% polskich naukowców w Kwiek 2019d oraz analizę „internacjonalistów” i „miejscowych” w badaniach naukowych w Kwiek 2019e; obie prace odnoszą się rzecz jasna również, chociaż pośrednio, do analizowanego obszaru). Bezprecedensowy rozkwit badań nad szkolnictwem wyższym w największych krajach Europy kontynentalnej, Australii, Wielkiej Brytanii i Nowej Zelandii można wyttumaczyć kilkoma czynnikami, m.in. spóźnionym umasowieniem szkolnictwa wyższego (w porównaniu z USA i Kanadą), nasileniem współpracy międzynarodowej (zob. Kwiek 2019b i Kwiek 2018b o Europie), a także tym, co Kandiko Howson (2018) określa jako hiperindywidualizm naukowców i metryfikację ekonomii prestiżu w szkolnictwie wyższym w tych systemach, wspieraną przez rygorystyczne procedury oceny wyników działalności badawczej.

Jednak pomimo tego bezprecedensowego globalnego wzrostu, niższy potencjał cytowań w dziedzinie badań szkolnictwa wyższego w porównaniu z innymi dziedzinami nauk społecznych może negatywnie wpływać na stabilność kariery akademickiej i przyszły dostęp do konkurencyjnego finansowania badań, zwłaszcza w krajach o silnych systemach oceny badań opartych na metrykach bibliometrycznych. Nie powinno to budzić zdziwienia, biorąc pod uwagę stosunkowo niewielką liczbę naukowców, którzy są mocno zaangażowani w tę dziedzinę, a w szczególności niewielki odsetek autorów publikujących liczne prace (naszych „pełnoetatowców”) zarówno w skali globalnej, jak i w Stanach Zjednoczonych, które są głównym producentem publikacji w tej dziedzinie. To właśnie pełnoetatowcy zazwyczaj prowadzą większość istotnych badań o wysokim potencjale cytowania - a jednak, pomimo globalnej ekspansji szkolnictwa wyższego, ich liczba pozostaje wciąż ograniczona.

W ujęciu publikacji zawartych w 41 podstawowych czasopismach w ciągu ostatniego ćwierćwiecza, globalna społeczność naukowa badaczy szkolnictwa wyższego w najszerszym ujęciu: autorstwa przynajmniej jednej publikacji - obejmuje nie więcej niż 27000 naukowców (chociaż za rzetelność danych dotyczących indywidualnych 
numerów identyfikacyjnych w bazie Scopus odpowiada jej komercyjny właściciel, Elsevier - pomimo naszych systematycznych metod szacowania błędów). Jednak skala ich udziału za pośrednictwem publikacji pozostaje rozczarowująco niska w kontekście społecznego i gospodarczego zjawiska globalnej ekspansji szkolnictwa wyższego. Analiza elitarnych (6) i podstawowych (41) czasopism wyraźnie wskazuje, że dla zdecydowanej większości badaczy w tej dziedzinie szkolnictwo wyższe nie jest głównym przedmiotem ich zainteresowań naukowych. Inaczej to ujmując, nie uważają oni (elitarnych i podstawowych) czasopism z dziedziny badań szkolnictwa wyższego za swoje główne ulokowanie naukowe. Spośród 26881 naukowców publikujących w czasopismach podstawowych 878 (około $3,3 \%$ ) było autorami lub współautorami co najmniej 5 artykułów w ostatnim ćwierćwieczu, w tym 274 (z 8226) w czasopismach elitarnych (3,3\%). Stanowią oni trzon publikacyjny globalnego środowiska naukowego badaczy szkolnictwa wyższego - to nasi „pełnoetatowcy”. Ośmiu na dziesięciu naukowców pozostaje na peryferiach publikacyjnych tego obszaru, będąc autorem lub współautorem jedynie pojedynczego artykułu w czasopismach elitarnych (78,8\%) lub podstawowych (79,5\%).

Około trzech czwartych autorów pełnoetatowców pochodzi z USA lub z innych systemów anglosaskich, podczas gdy 26,4\% (elitarne czasopisma) i 25,4\% (czasopisma podstawowe ) pochodzi z innych krajów. Autorzy niepełnoetatowcy wykazują podobną strukturę - 29,8\% autorów niepełnoetatowców w czasopismach elitarnych i 32,3\% w czasopismach podstawowych pochodzi z tych krajów. Zgodnie z oczekiwaniami dominacja amerykańska i anglosaska jest silniejsza w czasopismach elitarnych, które z reguły charakteryzują się dłuższą tradycją.

Wszechobecność autorów niepełnoetatowców (czyli tylko z jedną publikacją wydaną w czasopismach elitarnych i podstawowych w ostatnim ćwierćwieczu) przyczynia się do nadawania badaniom z zakresu szkolnictwa wyższego statusu dziedziny o niższym poziomie cytowalności niż w innych dziedzinach nauk społecznych. Wszechobecność rzadko pojawiających się autorów publikacji - w tym naszych „niepełnoetatowców” pojawiających się tylko raz - wyraźnie utrudnia dialog naukowy, zawsze napędzany publikacjami; wynikający z tego niski poziom zaangażowania w badania teoretyczne (Clegg 2012) może również przyczyniać się do postrzegania tej dziedziny jako niestabilnej (Jung i Horta 2013) czy niedojrzałej (Tight 2014). Nie wychodzimy tutaj jednak poza analizy wskaźnika CiteScore; oparte na danych longitudinalnych porównania z innymi dziedzinami nauk społecznych (w pełni wykonalne) wykraczają poza zakres problemowy niniejszego studium, ale kwestia ta wydaje się szczególnie istotna w obszarach multidyscyplinarnych.

Przedstawione tu wzorce autorstwa publikacji mogą mieć poważny wpływ na przyszłość badań nad szkolnictwem wyższym oraz naukowy sukces ich globalnych 
i krajowych społeczności. W ujęciu podłużnym, na przestrzeni ostatniego ćwierćwiecza, globalne środowisko badawcze szkolnictwa wyższego jest bardzo rozwarstwione; niewielu naukowców intensywnie publikuje w elitarnych i podstawowych czasopismach, a bardzo wielu publikuje tam tylko raz. Być może świadczy to o tym, że większość z nich (owi „niepełnoetatowcy”) to skoncentrowani na polityce edukacyjnej praktycy, administratorzy lub nauczyciele akademiccy nie zajmujący się badaniami naukowycmi, co przemawiałoby za określeniem tej dziedziny za Tight'em jako „ateoretycznej wspólnoty praktyków” oraz wspierałoby opinię Santosa i Horty (2018), że dziedzina ta jest zaludniona przez „niepełnoetatowców”, którzy niekoniecznie uważają się za zlokalizowanych w ramach badań nad szkolnictwem wyższym i różnią się zasadniczo od regularnych autorów badań w tym obszarze (Santos i Horta 2018). Naukowcy zajmujący się badaniem szkolnictwa wyższego mogą jednak konsekwentnie publikować (i mogą być konsekwentnie cytowani) w czasopismach wykraczających poza elitarne i podstawowe czasopisma w tej dziedzinie, na przykład w nieindeksowanych czasopismach dotyczących szkolnictwa wyższego (czyli o niższym statusie) lub w czasopismach z innych dziedzin. Mogą oni publikować w swoim języku ojczystym w obu typach czasopism, a także w książkach w tym języku lub w języku angielskim. W każdym razie pozostaje faktem, że dziedzina ta jest stosunkowo skromna pod względem liczby autorów (nawet biorąc pod uwagę aktualne niedoskonałości identyfikacji autorów w bazach typu Scopus), rozdrobniona, niedostatecznie zglobalizowana - i być może niedojrzała pod względem teoretycznym. Pytania o tożsamość tej dziedziny i jej przyszłość są stawiane od co najmniej pięćdziesięciu lat, a bardziej intensywnie od lat trzydziestu. Dziedziny to jednak instytucje długiego trwania, o których przyszłości decyduje kolektywny wysiłek badaczy na poziomie globalnym. Zakładamy, że w ujęciu globalnym czeka ją intensywny rozwój, zwłaszcza w związku z postępującą demonopolizacją geograficzną autorów i potencjalną, wynikającą z tego faktu, demonopolizacją teoretyczną. Nowa globalna geografia produkcji wiedzy obejmuje, jak szczegółowo pokazujemy, również analizowany obszar.

Jeśli większość wydawanych publikacji jest pisana przez autorów niepełnoetatowców, a tylko niewielki ich odsetek stanowią pełnoetatowcy (lub, jak pisze Tight (2018), bez szczegółowej definicji, „regularni” autorzy), to może się okazać, że trudno będzie osiągnąć dojrzałość teoretyczną w ramach toczącej się naukowej konwersacji. Wyniki naszych badań są zbieżne z wnioskami Jung i Horty dotyczącymi struktury środowiska badaczy szkolnictwa wyższego w Azji, gdzie w 66\% z 244 instytucji zajmujących się badaniami nad szkolnictwem wyższym opublikowano tylko jeden artykuł w latach 1980-2012, podczas gdy tylko w 15\% opublikowano dwa artykuły. Scharakteryzowali oni tę sytuację jako „niewielką liczbę instytucji spoczywających na barkach jeszcze mniejszej liczby badaczy" (2013: 411-412) - w niektórych przypadkach na barkach 
pojedynczych badaczy, co wydaje się odpowiadać globalnemu obrazowi przedstawionemu w niniejszym artykule.

Nasze ustalenia potwierdzają, że tylko dwa globalne czy międzynarodowe elitarne czasopisma (Higher Education i Studies in Higher Education) przyciągają z czasem coraz większy odsetek autorów nieanglojęzycznych i nieamerykańskich (zwłaszcza Europejczyków). Higher Education Research and Development pozostaje czasopismem anglosaskim, z niewielkim udziałem autorów z innych części świata. W związku z tym, podczas gdy grono tradycyjnych elitarnych czasopism pozostaje stabilne, najważniejsze cechy bibliometryczne potwierdzają, że tylko dwa z nich można uznać za międzynarodowe pod względem przynależności autorów do świata innego niż anglosaski. Interesującym pytaniem w ramach przyszłych badań jest to, czy tendencje te odzwierciedlają politykę redaktorów naczelnych i/lub recenzentów, czy też stanowią one sumę decyzji autorów o tym, gdzie wysyłać swoje teksty. Kwestia ta mogłaby zostać zbadana poprzez połączenie badań bibliometrycznych, ankietowych i wywiadów.

Nasze badania mają kilka ograniczeń. Po pierwsze nasza analiza nie obejmowała książek i rozdziałów książek, ale skupiała się na artykułach recenzowanych jako „złotym standardzie” w badaniach nad szkolnictwem wyższym (Tight 2018). Podczas gdy książki i rozdziały książek są niewątpliwie ważne dla indywidualnej pozycji i renomy w naukach społecznych, obecnie nie są dostępne wiarygodne globalne dane porównawcze dotyczące autorstwa książek i wzorców ich cytowania. Po drugie, pomimo powszechnego używania języków narodowych w badaniach nad szkolnictwem wyższym, 6 elitarnych i 41 podstawowych czasopism w szkolnictwie wyższym jest wydawanych wyłącznie w języku angielskim, a lista ta dodatkowo nie obejmuje wielu anglojęzycznych czasopism spoza bazy danych Scopus. Chociaż można byłoby sporządzić bardziej obszerną listę, to nie są dostępne odpowiednio szczegółowe dane bibliometryczne (zwłaszcza dotyczące cytowań). Równoległe badanie mogłoby być użyteczne dla przeanalizowania bazy danych Web of Science i jej systemu indeksacji, ale pokrycie w zakresie nauk społecznych jest większe w bazie Scopus (Sugimoto i Larivière 2018; Moya i in. 2007). Po trzecie wpływ badań nad szkolnictwem wyższym na różne zainteresowane strony wykracza daleko poza cytowania użyte tutaj jako przybliżony wskaźnik wpływu. Niemniej jednak cytowania zawierają „przebłysk zadłużenia” i sytuują „obecną wypowiedź w ramach całości konwersacji” (Budd i Magnuson 2010: 303) - w tym przypadku, w ramach literatury dotyczącej globalnych badań szkolnictwa wyższego. Wreszcie, niniejsze badanie ilościowe można uzupełnić badaniami jakościowymi, w tym ankietami o charakterze otwartym z pytaniami o rolę elitarnych czasopism w rozwoju kariery naukowej z międzynarodowej perspektywy porównawczej i wywiadami z redaktorami czasopism i kadrą akademicką. 
Na dzisiejszej wysoce konkurencyjnej globalnej arenie naukowej ścisły związek między publikowaniem w najlepszych czasopismach a sukcesem indywidualnym i instytucjonalnym (Marginson 2014; Rosinger i in. 2016) staje się bardziej zrozumiały w kontekście dwóch stanowisk teoretycznych: modelu maksymalizacji prestiżu i teorii agencji (pryncypała-agenta). Te dwie perspektywy badawcze postrzegają publikacje jako narzędzia generowania prestiżu i jako użyteczny, choć uproszczony wskaźnik dla pryncypałów (rządów, krajowych rad ds. badań naukowych i liderów uczelni) w ocenie jakości badań prowadzonych przez ich agentów (naukowców). Perspektywy te pomagają zrozumieć rosnące znaczenie najlepszych czasopism w globalnych badaniach nad szkolnictwem wyższym - podobnie jak w innych dziedzinach - pomimo dekoncentracji (pod względem czysto technicznym: udział artykułów, udział cytowań) rynku cytowań i rynku publikacyjnego, na co wskazuje malejący z czasem wskaźnik Herfindahla-Hirschmana.

W latach 1996-2018 łącznie zdecydowana większość globalnych badań nad szkolnictwem wyższym publikowanych w elitarnych czasopismach powstała w USA i innych krajach anglosaskich (70,0\%), w Europie kontynentalnej (16,7\%) i Azji Wschodniej (5,1\%). To są właśnie główni uczestnicy globalnej konwersacji naukowej, przy stopniowo rosnącym udziale innych regionów świata (8,2\%). Zmieniający się rozkład krajowych afiliacji autorów w okresie objętym badaniem wskazuje na szersze procesy mające wpływ na społeczność globalną. Dynamika zmian wskazuje na stopniowe osłabienie tej dziedziny w USA i jej relatywne wzmocnienie w Europie kontynentalnej, Azji Wschodniej i innych regionach świata. Podczas gdy trzy krajowe (tu: amerykańskie) czasopisma elitarne (JHE, ResHE i RevHE) pozostają silnie amerykańsko-anglosaskie pod względem wzorców autorstwa publikacji, globalny profil dwóch nieamerykańskich czasopism elitarnych (HE i SHE) odzwierciedla rosnącą rolę nieanglosaskich afiliacji autorskich.

Publikacje (zwłaszcza w najbardziej prestiżowych czasopismach) oraz konkurencyjne zewnętrzne finansowanie badań $\mathrm{w}$ coraz większym stopniu determinują nie tylko indywidualne możliwości prowadzenia badań - ale również finansowanie instytucjonalne i wydziałowe na uczelniach prowadzących intensywną działalność badawczą. Naukowcy publikujący na dużą skalę na wysokim poziomie generują środki na badania, podczas gdy naukowcy publikujący na małą skalę i na niskim poziomie przyciągają niewielkie środki finansowe; jednocześnie nowi badacze w dziedzinie szkolnictwa wyższego „muszą publikować więcej (i bardziej międzynarodowo) i pozyskiwać więcej (i bardziej międzynarodowo) środków finansowych na badania" (Santos i Horta 2018: 675). Innymi słowy poszukiwanie prestiżu na poziomie jednostkowym staje się ważniejsze niż kiedykolwiek wcześniej na poziomie instytucjonalnym, a poprzez krajowe i globalne rankingi - również na poziomie krajowym i międzynarodowym. 
Biorąc pod uwagę rosnące uzależnienie sukcesu akademickiego od wysoko cytowanych publikacji i konkurencyjnego, zewnętrznego finansowania badań naukowych, można oczekiwać, że rola elitarnych czasopism w analizowanej dziedzinie w nowej ekonomii prestiżu będzie w przyszłości jeszcze większa. Najprawdopodobniej wnioski te można przenieść na inne obszary nauki.

\section{Podziękowania}

Tekst jest ttumaczeniem pracy „The Prestige Economy of Higher Education Journals: A Quantitative Approach" złożonej w Higher Education. Autor wyraża wdzięczność za wsparcie otrzymane w projekcie MNISW Dialog (0022/DLG/2019/10). Istotny wkład do prowadzonych badań wniósł dr Wojciech Roszka z UEP w Poznaniu, członek zespołu badawczego Dialog, za co jestem mu ogromnie wdzięczny.

\section{Literatura}

Bak H.J. i Kim D.H. (2019). The unintended consequences of performance-based incentives on inequality in scientists' research performance. Science and Public Policy 46(2) 219-231.

Bayer A. E. (1983). Multi-method strategies for defining 'core' higher education journals. The Review of Higher Education 6(2) 103-113.

Blackmore P. (2016). Prestige in academic life: Excellence and exclusion. London and New York: Routledge.

Blackmore P. (2018). What can policy-makers do with the idea of prestige to make better policy? Policy Reviews in Higher Education 2(2) 227-254.

Blackmore P. i Kandiko C.B. (2011). Motivation in academic life: A prestige economy. Research in Post-Compulsory Education 16(4) 399-411.

Braun D. i Guston D.H. (2003). Principal-agent theory and research policy: An introduction. Science and Public Policy 30(5) 302-308.

Bray N.J. i Major C.H. (2011). Status of journals in the field of higher education. Journal of Higher Education 82(4) 479-503.

Budd M.J. i Magnuson L. (2010). Higher education literature revisited: Citation patterns examined. Research in Higher Education 51 294-304.

Burris V. (2004). The academic caste system: Prestige hierarchies in PhD exchange networks. American Sociological Review 69(2) 239-264.

Cantwell B. i Kauppinen I. red. (2014). Academic capitalism in the age of globalization. Baltimore: Johns Hopkins University Press.

Clegg S. (2012). Conceptualising higher education research and/or academic development as „fields”: A critical analysis. Studies in Higher Education 31(5) 667-678. 
Cruz-Castro L. Sanz-Menéndes L. (2010). Mobility versus job stability: Assessing tenure and productivity outcomes. Research Policy 39(1) 27-38.

Fender B.F. Taylor S.W. i Burke K.G. (2005). Making the big leagues: Factors contributing to publication in elite economics journals. Atlantic Economic Journal 33(1) 93-103.

Gomez-Mejia L.R. i Balkin D.B. (1992). Determinants of faculty pay: An agency theory perspective. Academy of Management Journal 35(5) 921-955.

Heckman J.J. i Moktan S. (2018). Publishing and promotion in economics. The tyranny of the Top Five. NBER Working Paper 25093.

Hirsch F. (1976). Social limits to growth. Cambridge: Harvard University Press.

Horta H. (2018). Higher-education researchers in Asia: The risks of insufficient contribution to international higher-education research. W: J. Jung H. Horta i A. Yonezawa (red.) Researching higher education in Asia. History development and future (ss. 15-36). Springer: Singapore.

Horta H. i Jung J. (2014). Higher education research in Asia: An archipelago two continents or merely atomization? Higher Education 68 117-134.

Hutchinson S.R. i Lovell C.R. (2004). A review of methodological characteristics of research published in key journals in higher education: Implications for graduate research training. Research in Higher Education 45(4) 383-403.

Jung J. i Horta H. (2013). Higher education research in Asia: A publication and co-publication analysis. Higher Education Quarterly 67(4) 398-419.

Kandiko Howson C.B. Coate K. i de St. Croix T. (2018). Mid-career academic women and the prestige economy. Higher Education Research and Development 37(3) 1-16.

Kivistö J. (2008). An assessment of agency theory as a framework for the government-university relationships. Journal of Higher Education Policy and Management 30(4) 339-350.

Kwiek, M. (2015a). Uniwersytet $w$ dobie przemian. Instytucje $i$ kadra akademicka $w$ warunkach rosnacej konkurencji, Warszawa: WN PWN.

Kwiek, M. (2015b). The internationalization of research in Europe. A quantitative study of 11 national systems from a micro-level perspective. Journal of Studies in International Education, 19(2), 341-359.

Kwiek, M. (2016). The European research elite: A cross-national study of highly productive academics across 11 European systems. Higher Education, 71(3), 379-397.

Kwiek, M. (2018a). Academic top earners. Research productivity, prestige generation and salary patterns in European universities. Science and Public Policy. 45(1). Luty 2018. 1-13.

Kwiek, M. (2018b). International Research Collaboration and International Research Orientation: Comparative Findings About European Academics. Journal of Studies in International Education. 22(2): 136-160.

Kwiek, M. (2018c). High Research Productivity in Vertically Undifferentiated Higher Education Systems: Who Are the Top Performers? Scientometrics. 115(1). 415-462. 
Kwiek, M. (2019a). Changing European Academics. A Comparative Study of Social Stratfication, Work Patterns and Research Productivity. London and New York: Routledge.

Kwiek, M. (2019b). Internationalisation of EU Research Organisations. A Bibliometric Stocktaking Study. Brussels: European Parliament (Panel for the Future of Science and Technology).

Kwiek, M. (2019c). Social Stratification in Higher Education: What It Means at the Micro-Level of the Individual Academic Scientist. Higher Education Quarterly. Vol. 73. Issue 4. 419-444.

Kwiek, M. (2019d). Kim są najbardziej produktywni polscy naukowcy? Produktywność badawcza w niezróżnicowanym i niekonkurencyjnym systemie nauki. Nauka i Szkolnictwo Wyższe. 1-2(53-54).

Kwiek, M. (2019e). Internacjonaliści i miejscowi: międzynarodowa współpraca badawcza w Polsce na mikropoziomie indywidualnych naukowców. Nauka i Szkolnictwo Wyższe. 1-2(53-54).

Kwiek, M. (2020a). Międzynarodowa współpraca badawcza w Europie w świetle dużych danych i jej globalne konteksty. Nauka 1(2020).

Kwiek, M. (2020b). Stratyfikacja społeczna w nauce: wprowadzenie. W: J. Brzeziński (red.), Uniwersytet XXI wieku: od Humboldta do Uniwersytetu 4.o, Poznań: Wydawnictwo Naukowe UAM, 2020. 131-158.

Laine C.R. (1995). The Herfindahl-Hirschman index: A concentration measure taking the consumer's point of view. The Antitrust Bulletin Summer 1995 432-432.

Larivière V. i Gingras Y. (2010). The Impact Factor's Matthew Effect. A natural experiment in bibliometrics. Journal of the American Society for Information Science and Technology 61(2) 424-427.

Latour B. i Woolgar S. (1986). Laboratory life. The construction of scientific facts. Princeton: Princeton University Press.

Marginson S. (2014). University research: The social contribution of university research. W: J.C. Shin i U. Teichler (red.), The future of the post-massified university at the crossroads. Restructuirng systems and functions (ss. 101-118). Dordrecht: Springer.

Melguizo T. i Strober M.H. (2007). Faculty salaries and the maximization of prestige. Research in Higher Education 48(6) 633-668.

Moed H.F. (2005). Citation analysis in research evaluation. Dordrecht: Springer.

Moya F. Chinchilla Z. Vargas B. Corera E. Munoz F. Gonzalez A. i Herrero V. (2007). Coverage analysis of Scopus: A journal metric approach. Scientometrics 73(1) 53-78.

Pratt J.W. i Zeckhauser R.J. (red.). (1985). Principals and agents. The structure of business. Boston: Harvard Business School Press.

Rosinger K.O. Taylor B.J. Coco L. i Slaughter S. (2016). Organizational segmentation and the prestige economy: Deprofessionalization in high- and low-resource departments. Journal of Higher Education 87(1) 27-54. 
Santos J.M. Horta H. (2018). The research agenda setting of higher education researchers. Higher Education 76(4) 649-668.

Silverman R.J. (1987). How we know what we know: A study of higher education journals. The Review of Higher Education 11(1) 39-59.

Slaughter S. i Leslie L.L. (1997). Academic capitalism: Politics, policies and the entrepreneurial university. Baltimore: Johns Hopkins University Press.

Sugimoto C.R. i Larivière V. (2018). Measuring research. What everyone needs to know. Oxford: Oxford University Press.

Taylor B. Rosinger K.O. i Slaughter S. (2016). Patents and university strategies in the prestige economy. W: S. Slaughter i B.J. Taylor (red.) Higher education stratification and workforce development (ss. 103-125). Dordrecht: Springer.

Tight. M. (2012). Higher education research 2000-2010: Changing journal publication patterns. Higher Education Research \& Development 31(5) 723-740.

Tight M. (2014). Working in separate silos? What citation patterns reveal about higher education research internationally? Higher Education 68(3) 379-395.

Tight M. (2018). Higher education journals: Their characteristics and contribution. Higher Education Research \& Development 37(3) 607-619.

Urbanek, P. (2018). Reform of the higher education system in Poland from the perspective of agency theory. European Journal of Higher Education. https://doi.org/10.1080/2156 8235.2018.1560344. Opublikowany: 20 grudnia 2018.

Van der Meulen B. (1998). Science policies as principal-agent games. Institutionalization and path dependency in the relation between government and science. Research Policy 27 397-414.

Whitley R. (2000). The intellectual and social organization of the sciences. Oxford: Oxford University Press.

Whitley R. i Gläser J. (red.) (2007). The changing governance of the sciences. The advent of research evaluation systems. Dordrecht: Springer. 


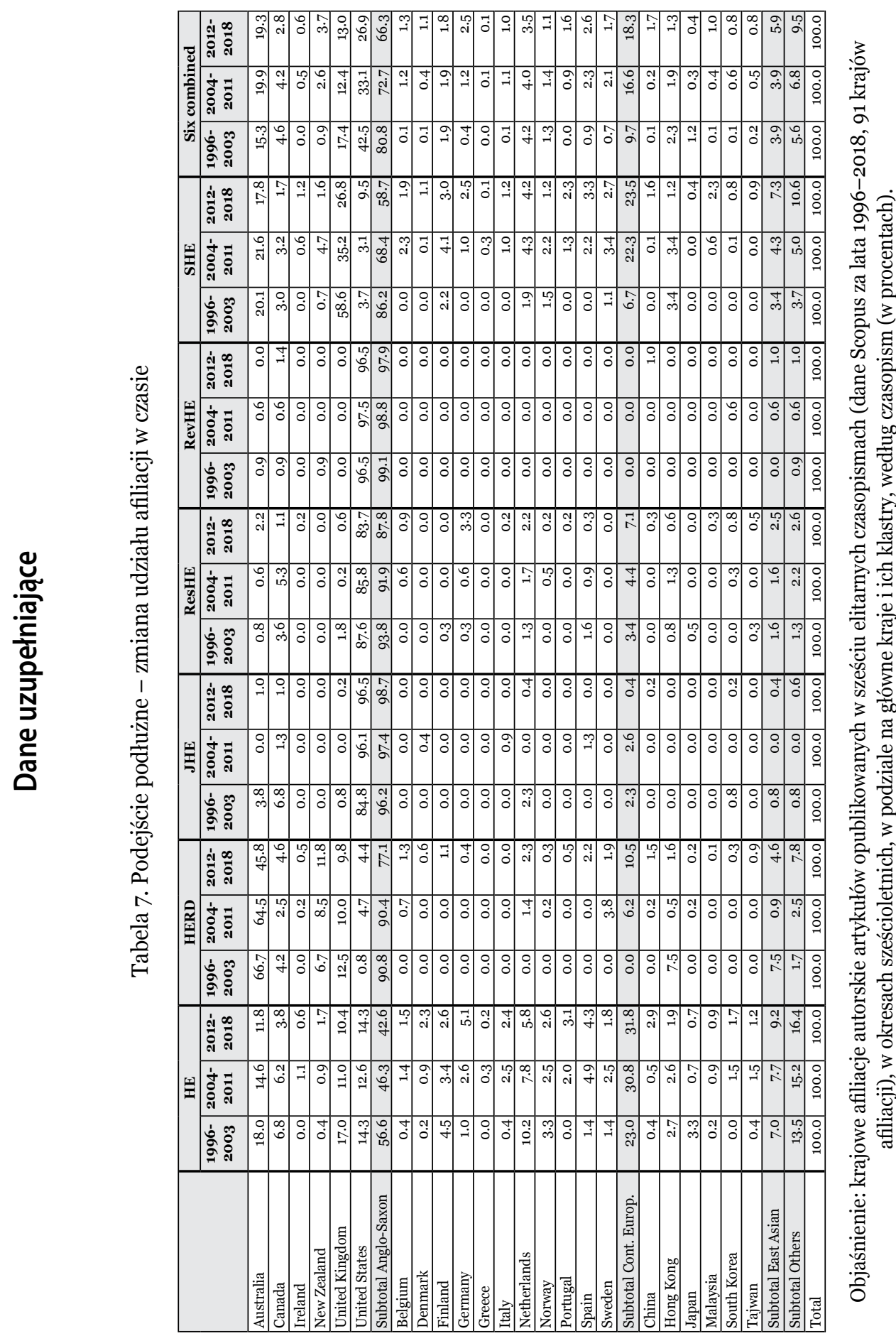


Tabela 9. Cytowania i artykuły w 41 czasopismach z dziedziny badań szkolnictwa wyższego

\begin{tabular}{|c|c|c|c|c|}
\hline & \multicolumn{2}{|c|}{ Citations } & \multicolumn{2}{|c|}{ Articles only } \\
\hline & $\mathbf{n}$ & $\%$ & $\mathbf{n}$ & $\%$ \\
\hline Higher Education & 6759 & 13.9 & 122 & 7.2 \\
\hline Studies in Higher Education & 6239 & 12.9 & 155 & 9.1 \\
\hline Internet and Higher Education & 4020 & 8.3 & 24 & 1.4 \\
\hline Research in Higher Education & 3821 & 7.9 & 44 & 2.6 \\
\hline Assessment and Evaluation in Higher Education & 3806 & 7.8 & 93 & $5 \cdot 5$ \\
\hline Higher Education Research and Development & 2985 & 6.1 & 99 & 5.8 \\
\hline Journal of Higher Education & 2792 & 5.8 & 24 & 1.4 \\
\hline International Journal of Sustainability in Higher Education & 2023 & 4.2 & 64 & 3.8 \\
\hline Teaching in Higher Education & 2011 & 4.1 & 62 & 3.6 \\
\hline Review of Higher Education & 1361 & 2.8 & 25 & 1.5 \\
\hline \begin{tabular}{|l|} 
Journal of Geography in Higher Education \\
\end{tabular} & 1277 & 2.6 & 39 & 2.3 \\
\hline Journal of Higher Education Policy and Management & 1049 & 2.2 & 40 & 2.3 \\
\hline Journal of Further and Higher Education & 1048 & 2.2 & 78 & 4.6 \\
\hline Active Learning in Higher Education & 941 & 1.9 & 42 & 2.5 \\
\hline Innovative Higher Education & 888 & 1.8 & 31 & 1.8 \\
\hline Higher Education Policy & 841 & 1.7 & 27 & 1.6 \\
\hline Higher Education Quarterly & 727 & 1.5 & 27 & 1.6 \\
\hline Quality in Higher Education & 722 & 1.5 & 18 & 1.1 \\
\hline Journal of Hispanic Higher Education & 606 & 1.2 & 24 & 1.4 \\
\hline Journal of Diversity in Higher Education & 598 & 1.2 & 42 & 2.5 \\
\hline Journal of Marketing for Higher Education & 584 & 1.2 & 16 & 0.9 \\
\hline Tertiary Education and Management & 560 & 1.2 & 28 & 1.6 \\
\hline Journal of Computing m Higher Education & 516 & 1.1 & 30 & 1.8 \\
\hline International Journal of Educational Technology in Higher Ed. & 482 & 1.0 & 48 & 2.8 \\
\hline Arts and Humanities in Higher Education & 371 & 0.8 & 24 & 1.4 \\
\hline Industry and Higher Education & 351 & 0.7 & 38 & 2.2 \\
\hline European Journal of Higher Education & 188 & 0.4 & 17 & 1.0 \\
\hline Higher Education. Skills and Work-based Learning & 170 & 0.4 & 35 & 2.1 \\
\hline Perspectives: Policy and Practice in Higher Education & 164 & 0.3 & 16 & 0.9 \\
\hline Journal of Continuing Higher Education & 157 & 0.3 & 23 & 1.3 \\
\hline Journal of Applied Research in Higher Education & 128 & 0.3 & 44 & 2.6 \\
\hline Christian Higher Education & 119 & 0.2 & 20 & 1.2 \\
\hline Journal of Higher Education Outreach and Engagement & 77 & 0.2 & 30 & 1.8 \\
\hline NASPA Journal About Women in Higher Education & 68 & 0.1 & 19 & 1.1 \\
\hline Art Design \& Communication in Higher Education & 44 & 0.1 & 13 & 0.8 \\
\hline Higher Education Pedagogies & 18 & 0.0 & 34 & 2.0 \\
\hline International Journal of Learning in Higher Education & 17 & 0.0 & 14 & 0.8 \\
\hline Language Learning in Higher Education & $\mathrm{S}$ & 0.0 & 28 & 1.6 \\
\hline International Journal of Higher Education & 6 & 0.0 & 109 & 6.4 \\
\hline Higher Education Forum & 5 & 0.0 & 30 & 1.8 \\
\hline Tuning Journal for Higher Education & $\mathrm{O}$ & 0.0 & $\mathrm{~S}$ & 0.5 \\
\hline Total & 48547 & 100 & 1704 & 100 \\
\hline
\end{tabular}

Objaśnienie: dane Scopus, 2018 (w kolejności malejącej, częstość i odsetek). 


\title{
The Academic Prestige Economy. A quantitative Approach to Elite Journals in the Field of Higher Education Research
}

\begin{abstract}
This study analyzes the stratification in the global higher education research community and the changing geography of author affiliations in the six elite journals in the area. The model of prestige maximization by institutions and scientists and the principle-agent theory constitute the two theoretical framework of the study, which includes 6,334 articles published in six elite journals between 1996 and 2018 in the context of 21,442 articles published in 41 basic journals in the area studied. Comparisons are made between full-timers and part-timers in higher education research and the distribution of their country affiliation is analysed from the longitudinal perspective of the last quarter of the century. The results indicate that about $3.3 \%$ of researchers publishing in both elite and core journals are authors of at least 5 articles between 1996 and 2018 and they are the backbone of the global research community, while $80 \%$ of researchers who are authors of only one article are its periphery. Higher Education and Studies in Higher Education journals are emerging as global elite journals, with a growing share of non Anglo-Saxon authors. Global trends in higher education research include the declining role of American scholars and the growing role of scholars from continental Europe and East Asia.
\end{abstract}

KEYWORDS: academic prestige, quantitative approach to research, academic journal stratification; prestige publications, presige economy, principal-agent theory, prestige maximization model, global science

CYTOWANIE: Kwiek, M. (2019). Ekonomia prestiżu akademickiego. Ilościowe ujęcie najlepszych czasopism na przykładzie dziedziny badań nad szkolnictwem wyższym. Nauka i Szkolnictwo Wyższe. 1-2(53-54): 11-46. DOI: 10.14746/nisw.2019.1-2.1.

MAREK KWIEK - prof. dr hab., dyrektor Centrum Studiów nad Polityką Publiczną (od 2002) i kierownik katedry UNESCO Badań Instytucjonalnych i Polityki Szkolnictwa Wyższego (od 2012) na UAM w Poznaniu. Zajmuje się ilościowymi badaniami nauki, socjologią karier akademickich i badaniami nad szkolnictwem wyższym. Jego zainteresowania naukowe koncentrują się na teoriach międzynarodowej współpracy naukowej, produktywności badawczej, stratyfikacji w nauce i badaniu globalnych elit akademickich, łącząc międzynarodowe badania ankietowe i badania bibliometryczne. Opublikował ok. 200 prac, a jego najnowsza monografia to Changing European Academics: A Comparative Study of Social Stratification, Work Patterns and Research Productivity (Routledge 2019). Był kierownikiem w 25 międzynarodowych projektach badawczych i w ostatniej dekadzie dla swoich zespołów badawczych zdobył w formie grantów $8 \mathrm{mln}$ PLN. Jest członkiem rady redakcyjnej Higher Education Quarterly, European Educational Research Journal, British Educational Research Journal oraz European Journal of Higher Education, www.cpp.amu.edu.pl.

E-mail: kwiekm@amu.edu.pl 